\title{
Kur'an Perspektifinden Pişmanlık ${ }^{*}$
}

\section{Handan Yalvaç Arıci**}

Atıf/C: Yalvaç Arıcı, Handan, Kur'an Perspektifinden Pişmanlık, Artuklu Akademi, 2020/7 (2), 417-448.

Öz: Kur'an, Allah'ın zihinleri ve gönülleri inşa ettiği, hayatları düzenleyen ilahi bir mesajdır. Bu ilahi mesaj insanın düşünce sistematiğini ve eylemlerini organize etmesine rehberlik etmektedir. Kur'an bireyin tasavvurunu inşa ettikten sonra hangi eylemlerin sonucunda pişmanlık yaşayacağını bildirmekte, dünyada ve ahirette hem bireysel hem de toplumsal olarak yaşanacak pişmanlıkları detaylı bir biçimde açılamaktadır. Günümüz insanının Kur'an'dan uzaklaşarak dünyevileşmiş bir yaşam tarzını tercih etmesi aynı zamanda Allah'ın belirlediği sınırları aşarak tatmin arayışında olması bireysel ve toplumsal olarak pişmanlığa zemin hazırlamaktadır. Pişmanlık tecrübesi, bireyin hatalarından, yanlışlarından dönebilme iradesi göstermesi ve Allah'tan mağfiret dileyerek gönlünü günah yükünden hafifletmesini ifade etmektedir. Tövbesi olan pişmanlık bir farkındalık eylemi ve doğru olana yönelme iradesidir. Bu çalışmada Kur'an perspektifinden bireysel ve toplumsal olarak dünyada ve ahirette yaşanacak pişmanlıklar değerlendirilmekte, ahirette pişman olan kişilerin talepleri anlatılmakta, peygamberlerin pişmanlık ve tövbeleri açıklanarak insanlık tarihinde insanlara rol model olmuş kişilerin tecrübeleri analiz edilmekte ve pişmanlığın yönetimi ortaya koyulmaktadır.

Anahtar Kelimeler: Kur'an, Pişmanlık, Tecrübe, Tövbe, Farkındalık

\section{Regret from the Perspective of the Qur'an}

Citation/@: Yalvaç Arıcı, Handan, Regret from the Perspective of the Qur'an, Artuklu Akademi, 2020/7 (2), 417-448.

\begin{abstract}
The Holy Quran is a divine message of Allah which builds the minds and souls, organizes the lives. This divine message guides human to organize his manner of embracing an idea and of behaviour. The Quran states in detail what actions the individual will regret after constructing his/herdisernment, and explains in detail the regrets that will be experienced both individually and
\end{abstract}

\footnotetext{
* Bu makale 2015 yılında tamamlanan "Kur'an'da Pişmanlık Psikolojisi" başlıklı yüksek lisans tezimden üretilmiştir.

** Dr., İstanbul Sabahattin Zaim Üniversitesi İslami İlimler Fakültesi, handanyalvac1453@gmail.com.
} 
socially in the world and in the hereafter. Today, the decision of prefering a profanelife style going far away from the Holy Quran and seeking for the satisfaction, going beyond to Allah's borders, lead up to a regret on individual and social basis. The experience of regret refers to the individual's willingness to retreatfrom his mistakes and to relieve his heart from the burden of sin by asking forgiveness from Allah. Regret with repentance is an act of awareness and the will to turn to the righteous act. In this study, individual and social regrets to be experienced in the world and the hereafter are evaluated throughthe perspective of the Qur'an, the demands of those who regret in the hereafter are explained; the repentance and regrets experienced by the prophets are explained, and the experiences of those who have been a role model for people in thehistory are analyzed and the management of regret is revealed.

Keywords: Qur'an, Regret, Experience, Repentance, Awareness.

\section{Giriş}

Allah insanı en güzel şekilde yaratmış ve ontolojik serüveninde kendisini kemale götürecek potansiyel ile donatmıştır. Aklı sayesinde iyi ile kötüyü birbirinden ayırt edebilmesi, özgür iradesiyle bir eylemi yapıp yapmamaya karar verebilme yetisine sahiptir. Tercihlerden oluşan her davranışın sorumluluğu bireyin kendisine aittir. İnsanı muhatap alan vahiy doğru yolun ne olduğunu ve neticesinde alınacak ödülü aynı zamanda yanlış yolların ne olduğunu ve sonunda karşılaşılacak cezayı bildirdikten sonra sorumluluğu muhatabına yüklemektedir. İlahi mesajdan uzak olan, tasavvurunu ve eylemini ilahi kaynaktan almayan kimseler için pişmanlık duygusu kaçınılmaz olmaktadır. Kimi zaman acelecilikten kimi zaman erteleme psikolojisinden kaynaklanan "Keşke yapmasaydım." veya "Keşke yapsaydım." gibi ifadeleri pişmanlığın söyleme yansımasıdır. Pişmanlık farklı davranılsaydı şimdiki durumdan daha iyi olabileceği düşünülen duyguya dayalı bilişsel ve olumsuz durumu ifade etmekte, ${ }^{1}$ mevcut durumun şimdikinden daha iyi olacağı anlaşıldığında veya öyle olduğu düşünüldüğünde yaşanılan olumsuz ve bilişsel bazlı bir duygu olarak tanımlanmaktadır. ${ }^{2}$

“Kur'an'da Pişmanlık" konulu birkaç yüksek lisans çalışması bulunmaktadır. Bu çalışmada pişmanlık konusu daha detaylı bir şekilde işlenmektedir. Bu çalışmada nitel araştırma yöntemlerinden içerik analizi

\footnotetext{
Daniel T. Gilbert v.dğr., "Looking Forward to Looking Backward The Misprediction of Regret, Pyschological Science", Research Report; 15/5 (2004), 346.

2 Zeelenberg, "The Use of Crying Over Spilled Milk: A Note on the Rationality and Functionality of Regret" Philosophical Pyschology, 12/3 (1999), 325.
} 
yöntemi kullanılmakta, pişmanlık konusu Kur'an perspektifine dayandırılarak ana ve alt kategorilere ayrılmakta, aktif ve pasif boyutuyla değerlendirilmektedir. Kişiyi harekete geçiren, tövbesi olan pişmanlık "aktif pişmanlık"; kişiyi harekete geçirmeyen, tövbesi olmayan pişmanlığı "pasif pişmanlık" olarak tanımlanmaktadır. Peygamberlerin yaşadıkları pişmanlıklara ve tövbelerine değinilerek pişmanlık konusu örnek modeller üzerinden işlenmektedir. Dünyada yaşanan pişmanlığın, işlenen hata ve günahlara tövbe edildiğinde bir imkân olduğu, tövbe edilmediğinde o hataları büyütmeye neden olduğu gösterilmekte, ahirette yaşanacak pişmanlıkların ise geri dönüşü olmayan imkansızlıklar barındırdığı anlatılmaktadır. Araştırma sonucunda elde edilen sonuçlara göre pişmanlığın doğru yönetilmesi için tasavvur ve eylemlerin nasıl inşa edilmesi gerekliliği ortaya konmaktadır.

'Pişman' kelimesi Fars dilinden Türk diline geçmiş olup etimolojik olarak kelimenin kökü Sanskritçeye dayanmaktadır. 'Pişman' sözcüğü bir şeyi arkasından anlama, öğrenme manalarına gelmektedir. ${ }^{3}$ Insan varlığ 1 genellikle bir eylemi gerçekleştirdikten sonra o eylemi değerlendirmekte ve yanlış olup olmadığına karar vermektedir. Bir başka ifadeyle eylemlerin sona ermesiyle birlikte değerlendirme alanı ortaya çıkmaktadır. Nasıl ki, dağcılık sporu yapan bir kişi zirveye vardığında kat etmiş olduğu yolu kuşbakışı görebilir, yolun kıvrımlarını, dönemeçlerini, ayağına takılmış olan taşları, yürüyüşündeki hataları fark edebilir, insan varlığı da eylemlerini gerçekleştirdikten sonra anlamlandırabilme ya da hayatının belirli bir döneminde yaşadıklarıyla yorumlayabilme imkânı bulmaktadır. ${ }^{4}$ Farsça ve Osmanlıcada mahşer gününe "Ruz-i Peşmani: Pişmanlık Günü"5 denilmesi bu noktada önem arz etmektedir. Çünkü insanın hayatı boyunca yapmış olduğu yanlışları ve hataları kuşbakışı görüp o hataların pişmanlığıyla karşı karşıya kalacağı gün olması hasebiyle mahşer günü bu isimle anılmaktadır.

Türkçemizde "Pişman"; 'Yaptığı bir işin veya davranışın olumsuz sonucunu görerek üzülen, nadim olan ' anlamına gelmektedir.6 Pişmanlık ise, 'Pişman olma durumu, nedamet' demektir. ${ }^{7}$ Arapça bir kelime olan "nedamet" sözcüğü; işlenen kötülükten dolayı üzüntü ve pişmanlık duyma

Muhammed Ali Dai İslam, Ferheng-i Nizam: Farisi Ba Farisi (Tahran: Şirket-i Daniş, 1362), II, 10.

Arthur Schopenhauer, Yaşam Bilgeliği Üzerine Aforizmalar, (İstanbul: Türkiye İş Bankası Kültür Yayınları, 2011), 124.

5 Ferit Devellioğlu, Osmanlıca-Türkçe Ansiklopedik Lügat, (Ankara: Kurtuluş Ofset Basımevi, 1984), "Ruz-i Peşmani", 1034.

6 Şükrü Haluk Akalın vd., Türkçe Sözlük, (Ankara: Türk Dil Kurumu, 2011), "Pişman”, 1929.

7 Akalın vd., "Pişmanlık", 1929. 
anlamında ahlaki terim olarak kullanılmaktadır. "Pişman" terimi, psikoloji sözlüğünde "Genellikle, kişinin geçmişte yaptı̆̆ı bir davranışı, farklı yapsaydı ya da olaylar daha farklı gelişseydi, işin daha iyi sonuçlanabileceğine dair duygu", 9 psikanaliz sözlüğünde "Üzüntü, keder ve yası andıran durgun bir duygulanım", 10 ahlak terimleri sözlüğünde ise "yapılan kötü bir işe veya davranışa vicdanen üzülme ve bu kötülükleri, bir iç muhasebe ve muhakeme ile bir daha yapmamaya kararl görünme, bir daha suç ve günah işlenmeyecek yine dair söz verme" 11 olarak tanımlanmaktadır. Suçluluk; "Bir suçu işlemek veya suça bulaşmaktan ötürü meydana gelen rahatsızlık." diye tanımlanırken, ${ }^{12}$ suçluluk duygusu; 'Kişinin ahlaki dini kurallarn çiğnediğini sezmesi sonucu bilinçli veya bilinçsiz olarak kapıldığı ve kendisiyle ilgili değer yargıların sarsan duygu, suçluluk hissi" 13 diye tarif edilmektedir. Hayal kırıklığı (inkisar-1 hayal, sukut-u hayal) ise "Çok istenilen veya umulan bir şeyin gerçekleşmemesinden duyulan üzüntü duymak"14 anlamina gelmektedir.

Bilimsel çalışmalarda pişmanlık duygusunun hayal kırıklığı ve suçluluk duygularından farklı bir duygu olduğu belirtilmektedir. Hayal kırıklığı; kontrol edilemeyen olaylar sebebiyle ya da başka bir kişinin sebep olduğu beklenmedik olumsuz olaylara karşı duygusal bir tepki, ${ }^{15}$ suçluluk duygusu ise kişilerarası ve içsel zarardan kaynaklı olarak yaşanan duygu süreçlerini ifade etmektedir. Suçluluk duygusu kişinin öz benliğine zarar vermektedir. 16 Pişmanlık duygusu ise bireyin mevcut durumunun şimdikinden daha iyi olacağını anladığında veya öyle olduğunu düşündüğünde yaşadığı olumsuz ve bilişsel temeli olan bir duygu olarak tanımlanmaktadır. 17 İnsan yaşadığı durumdan daha iyi bir durum yaşayabileceğini düşündüğünde pişmanlık duygusu tezahür etmeye başlamaktadır. Dünle bugün arasında olumsuz bir farklılık, yaşanabilecek olumlu bir durumu yaşayamamak pişmanlık duygusunu açı̆̆a

\footnotetext{
8 Özcan Taşçı, "Nedâmet", Türkiye Diyanet Vakfı İslâm Ansiklopedisi, (Ankara: TDV Yayınları, 2006), XXXII, 509.

9 Arthur S.Reber, The Pengiun Dictionary of Psychology, (London: Pengiun Books, 1985), “Regret”, 62.

10 Charles Rycroft, Psikanaliz Sözlüğü, çev. M. Sağman Karatekin (İstanbul: Ara yayınları, 1989), "Regret", 170.

11 Ali Seyyar, Ahlak terimleri (Ansiklopedik Sözlük) : Ingilizce-Almanca karşılıklı Türkçe açıklamalı, (İstanbul : Beta Basım Yayım , 2003), "Pişmanlık", 323.

12 D. Mehmet Doğan, Doğan Büyük Türkçe Sözlük, (Ankara: Vadi Yayınları, 2003), "Suçluluk”, 1205.

13 Akalın, "Suçluluk duygusu", 2167.

14 Akalın, "Hayal Kırıklığı", 1068.

15 Marcel Zeelenberg v.dğr, “On Bad Decisions and Disconfirmed Expectancies: The Psychology of Regret and Disappointment", Cognition and Emition, 14/4 (2000): 523.

16 Marcel Zeelenberg-Seger M. Breugelmans, "The Role of Interpersonal Harm in Distinguishing Regret From Guilt", Emotion, 8/5 (2008): 589.

17 Zeelenberg, "The Use of Crying Over Spilled milk: A Note On The Rationality and Functionality Of Regret", Philosophical Psychology, 12/3 (1999): 325.
} 
çıkarmaktadır. Suçluluk duygusu insanı bunalıma sürükleyebilmekte ve kişinin özsaygısını kaybetmesine neden olmaktadır. Hâlbuki pişmanlık deneyiminde kişi, özsaygısını yitirmeden eylemlerini gözden geçirmekte ve kendisini özsaygıyla eleştirmektedir. Dolayısıyla pişmanlık kişinin kendisine değil eylemine odaklanmasını sağlamaktadır.

İslam düşüncesinde pişmanlık deneyimiyle ilgi farklı görüşler bulunmaktadır Ebu'1 Hüzeyl18 ${ }^{18}$ renkleri herkesin göz organı ile görülmesine rağmen renklerin farklı algılayabilmesi gibi pişmanlığın da her birey tarafından farklı hissedilen bir duygu olduğunu söylemektedir. Ona göre her birey kendi donanımına göre yaptığı eylemden pişmanlık duymakta, kimisi için pişmanlık olabilecek bir eylem kimisi için pişmanlık sebebi olarak görülmemektedir. Dolayısıyla pişmanlığı inancın dışında bir olgu olarak yorumlamaktadır. Ebu Haşim ${ }^{19}$ ise pişmanlığı itikat cihetinden açıklamakta, kişinin yaptığı eylemin zararlı olduğuna inanması ve bundan pişman olma itikadına sahip olması şeklinde yorumlamaktadır. ${ }^{20}$ Bir başka ifadeyle Ebu Haşim'e göre hataların, günahların kötülüğü ve zarar alenidir ve herkesin bu davranışların yanlış olduğuna mutlak olarak inanması gerekmektedir. Gazali, pişmanlık duygusunun kişinin yaptığı hatanın zararını anlamasıyla, kulun Yaratıcısıyla arasında perde olduğunun ve ilişkisinin zedelendiğinin farkına varmasıyla kalpte oluşan bir elem, bir acı hissi olduğunu ifade etmektedir. Bireyin kendi hatası sebebiyle sevdiğini veya önem verdiği bir şeyi kaybettiğini fark ettiği anda, kalpte oluşan bu acının davranışları etkilediğini iddia etmektedir. ${ }^{21}$

Pişmanlık bireyi doğru davranışa götürmüyorsa, o yanlış davranış alışkanlık hâline gelmektedir. Alışkanlıkları değiştirmek zor olduğu için yapılan hatalar tekrarlandıkça pişmanlık yaşamak kaçınılmaz olmaktadır. Antik Çağ düşünürlerinden Epiktetos pişmanlığın tedavisi için yanlış alışkanlıkların doğruya kanalize edilmesi gerektiğini düşünmektedir. Alışkanlıkların değiştirilmesi için "Alışkanlıklarını karşıt alışkanlıklarla boyunduruk altına al. Şehvete mi düşkünsün, kendini ondan mahrum

\footnotetext{
18 Ebu'l-Huzeyl el-Allâf, (Ö. 816 ya da 840) İslam felsefesinde rasyonel din düşüncesinin ortaya çıkışında önemli rolü olan bir düşünürdür.

19 Ebû Hâşim el-Cübbâî (ö. 321/933). Mu'tezile kelamcılarından, İslam felsefesinin önemli düşünürlerinden biridir.

20 Kadı Abdülcebbâr, Şerhu'l-Usuli'l-Hamse, çev. İlyas Çelebi (İstanbul: Türkiye Yazma Eserler Kurulu Başkanlığı, 2013), 752-754.

21 Ebu Hamid Muhammed Gazalî, İhya-u Ulumi'd-Din, çev. Ahmed Serdaroğlu (İstanbul: Bedir Yayınevi, t.y.), 4,9 .
} 
ederek onu boyunduruk altına al. Tembel misin? İşe sarıl." 22 önerisinde bulunmaktadır. Pişmanlık tecrübesi sadece kişinin kendisine yakışmayan bir davranışı gerçekleştirmesi ya da topluma karşı yanlış davranışlar sergilemesi sonucunda ortaya çıkmamaktadır. Kulun Allah'ın emirlerinin dışına çıkarak yaptığı hata ve günahlar da pişmanlık vesilesidir. Yapılan hata ve günahlardan uzaklaşıp salih amel yolcusu olmaya karar vermek aktif bir pişmanlıktır.

Kur'an'da kulun hatasından ve günahından pişman olup Allah'a yönelmesi tövbe olarak ifade edilmektedir. ${ }^{23}$ Tövbe yapılan yanlış eylemlerden pişmanlık duymak ve doğru eylemlere yönelişi ifade etmektedir. Hz. Peygamber 'Pişmanlık tövbedir' diyerek pişmanlığın farkındalık eylemi olduğunu ve hatadan dönüldüğünde gerçekleştiğini bildirmektedir. ${ }^{24}$ Birçok tanımı olmakla birlikte tövbe, geçmişte yapılan hatalara pişman olup, gelecekte o hataları yapmamakta kararlı olmaktır. ${ }^{25}$ Tövbenin tövbe olabilmesi için pişmanlık duymak ve hatayı terk etmede kararlılık göstermek şeklinde iki şartının olduğu kabul edilmektedir. ${ }^{26}$ Pişmanlığın içine saplanıp kalmak bireyi kendinden uzaklaştıran, içini yiyip bitiren, ona bunalımlar yaşatan bir durumdur. Hâlbuki tövbesi olan pişmanlık kalbi teskin eden, umutla hayata bağlayan bir imkândır.

\section{Kur'an'da Pişmanlık Kavramı}

Kur'an'da pişmanlık tecrübesi birçok kelimeyle ve beden diline dair ifadelerle tasvir edilmektedir.

\section{A. Kur'an'da Pişmanlık Ifade Eden Kelimeler}

Hasretün (حَسْرَة Pişmanlığın en son durumuna denir. Yani, pişmanlığın insanı tamamen kuşatması durumudur. ${ }^{27}$

Leyte (ََيَتَّ): Temenni edatıdır. Gerçekleşmeyecek istekler için kullanılmaktadır. ${ }^{28}$ Kur'an' da farklı formlarda on beş defa kullanılmaktadır.

Epiktetos, Düşünceler ve Sohbetler, çev. Cemal Sürer (İstanbul: Kaknüs Yayınları, İstanbul. 1999), 129.

Hüseyin Atay, “Kur'an'a Göre Tövbe ya da Bilinci Yenilemenin İmkânı”, İslamiyat Dergisi, 1/.3 (1998): 93.

4 Ahmed b Hanbel, Müsned, (Beyrut: Mektebetü'l-İslamî, 1405/1985), I, 376.

25 Fahrettin Razi, Tefsîrü'l-Kebir (Mefatihu'l-Gayb), çev. Sadık Kılıç v.dğr., (İstanbul: Huzur Yayınevi, 2002), XXI, 561

26 Razî, Mealimu Usul'id Din (İslam İnancının Ana Konuları), çev. Nadim Macit, (Erzurum: İhtar Yayıncılık, 1996), 126.

27 İbn Manzur, Ebu'l-Fadl Cemalüddin Muhammed b. Mükerrem Ibn Manzur, Lisanu'l-Arabi'l-Muhit (Beyrut:Dâru'l-Fikr, 199), "hasretün", IV, 189.

28 İbn Manzur, "leyte", XII, 373. 
Mulîm (مُلِيمٍ): Kınanan, kınanacak bir iş yapan kişi, kınamaya vesile olacak kişi anlamlarına gelmektedir. ${ }^{29}$ Pişmanlı̆̆1 ifade eden bu kavram Kur'an'da iki yerde geçmektedir.

Nedâmet (نَدَمَة): Yapılan bir şey için üzüntü duymak, pişman olmak demektir. ${ }^{30}$

Veyl (وَيْلُ): Azabı ve helaki anlatan bir kelimedir. Pişmanlığı ifade etmek için kullanılmaktadır. ${ }^{31}$

Yâ Veyletâ (يَاَيْيَنَنَ) : Yâ tenbih edatıdır. Veyletâ ise "Veyl” kökünden türemiş olup, pişmanlık manasınadır. ${ }^{32}$

\section{B. Kur'an'da Pişmanlığın Beden Diliyle İfadeleri}

Kur'an'da pişmanlık kelimelerle ifade edildiği gibi beden diliyle de ifade edilmektedir. Başın eller arasına alınması, ellerin 1sırılması, elleri ovuşturmak gibi bedensel ifadelerle pişmanlık duygusu anlatılmaktadır.

Başı ellerine düşmek: Kur'an'da "elleri üzerine düşürüldü" 33 ifadesi pişmanlık için kullanılmaktadır. İnsanlar pişman oldukları zaman ellerini başlarına koyarak ya da başlarını elleri arasına alarak pişman olduklarını göstermektedirler. Araplar, yaptıkları bir davranıştan dolayı pişmanlıklarını "elleri üzerine düşürüldü" diye ifade etmektedirler. Bu ifade "başlarını ellerinin arasına alırlar" anlamına gelmektedir. ${ }^{34}$ Başın ellerin arasına alınması veya başın ellerin arasına düşmesi pişmanlığın bedensel ifadesi olarak kullanılmaktadır.

Elleri 1sırmak: Kur'an'da yaptığı işten çok pişmanlık duyan, bir şeyi elinden kaçıran bir kişinin pişmanlığı o kişinin ellerini ısırması olarak ile ifade edilmektedir. ${ }^{35}$ Kur'an'da “"Ellerini 1sırmak” deyimi pişmanlığın bedensel ifadesi olarak kullanılmaktadır. Pişmanlık yaşayan kişilerin bu duygularını ellerini ısırarak ifade etmeleri bu duygunun yoğunluğunun bedensel olarak ortaya konmasıdır. ${ }^{36}$

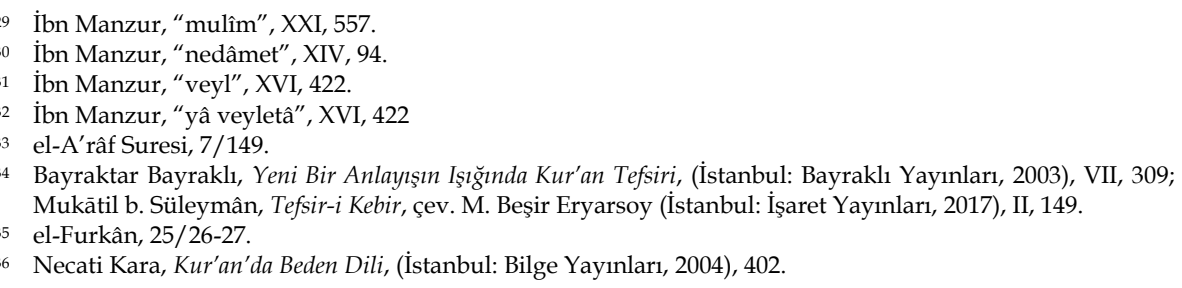


Elleri ovuşturmak: Kur'an'da "elleri ovuşturmak" deyimi pişmanlığın beden dilindeki ifadesi olarak kullanılmaktadır. ${ }^{37}$ Türkçede "Elleri ovuşturmak" olumlu beklentiler için kullanılan beden diline ait bir

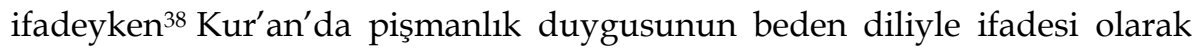
geçmektedir.

\section{Dünyadaki Pişmanlıklar}

Kur'an'da insanların dünya ve ahiret hayatında yaşayacakları pişmanlıklar ve bu pişmanlıkların nedenleri anlatılmaktadır. Dünyada yaşanan pişmanlıkların geri dönüşü bulunmakta ve pişmanlık tövbe edilerek ve davranış değişikliğiyle aktif bir duruma gelebilmektedir. Kur'an'da geçen dünyada yaşanan pişmanlıklar sekiz başlık altında toplanabilmektedir.

\section{Nefse Uyarak Yapılan Hatalardan Duyulan Pişmanlık}

Nefse uymak sebebiyle yapılan hatadan dolayı meydana gelen pişmanlığın ilk insandan itibaren başladığı bilinmektedir. İlk insan olan Hz. Adem'in pişmanlığı insanlık tarihinin ilk pişmanlık tecrübesidir. Kur'an'a göre ikinci pişmanlık Hz. Adem'in çocukları arasında yaşanan, kardeşlerden birinin diğerini öldürmesine kadar giden, nefse uyularak yapılan eylem sonucunda yaşanan pişmanlıktır. ${ }^{39}$ Bireyi pişmanlığa götürecek en önemli faktörlerden biri nefsine uyması, süfli duygularının esiri olmasıdır. Davranışları akla göre değil, nefsani duygulara göre gerçekleştirmek çoğu zaman hatalar, yanlışlar meydana getirmektedir. Kur'an'da Habil ve Kabil üzerinden verilen örnekte kıskançlık duygusuna kapılıp kardeşini öldüren Kabil'in durumu anlatılmaktadır. Hz. Adem'in iki oğlunun Allah için kurban ibadetinde bulundukları, Habil'in kurbanının kabul edilip Kabil'in kurbanının kabul edilmemesi sonucunda Kabil'de kıskançlık duygusunun harekete geçtiği ve kardeşini öldürdüğü bildirilmektedir. Kur'an'da Allah ibadetteki kabul şartını takvaya bağlamakta, Habil'in kurbanının kabul edilmesinin onun kurban ibadetindeki samimiyeti ve takvasıyla ilgili olduğu ifade edilmektedir. ${ }^{40}$ Kabil ise nefsine uyduğu ya da nefsi bu eylemi kendisine önemsiz gösterdiği için kardeşini öldürmüş, tarih sahnesinde

\footnotetext{
el-Kehf, 18/42.

Oğuz Saygın-Şafak Layiç, Resimli Beden Dili, (İstanbul: 4x4 Yayıncılık, 2006), 159.

el-Mâide, 5/27-31.

40 Ebu'l-Kasım Cârullah Mahmud b. Ömer Zemahşerî, Keşşâf Tefsiri, çev. Abdülaziz Hatip (İstanbul: Türkiye Yazma, Eserler Kurumu Başkanlığı, 2017), C. 2, s. 418; Bayraklı, Yeni Bir Anlayışın Işı̆̆ıı da Kur'an Tefsiri, v, 529
} 
kardeşini öldüren ilk kişi olarak yer almıştır. Maalesef insan varlığı kasten ve haksız yere adam öldürmenin büyük günahlardan olduğuna inansa da nefis çeşitli vesveselerle bu günahı küçük gösterip, yanlışı yapmada kişiye cesaret verebilmektedir. ${ }^{41} \mathrm{Bu}$ konuyla ilgili ayetlerde Kabil' in kardeşini nasıl defnedeceğini bir kargadan öğrendiği için hayıflandığı, pişman olup "Yazıklar olsun bana!" diyerek kardeşinin cesedini gizlemek için karga gibi bir çözüm bulamadığından kendisini hakir gördüğü, 42 pişmanlığı ve Allah'ın azabına müstahak olduğunun farkına vardığı ifade edilmektedir. ${ }^{43}$

\section{2. İnatçı Olmaktan Duyulan Pişmanlık}

İnsanı pişmanlığa sevk eden ve pişmanlık duygusunu yaşatan bir davranış biçimi de inatçı olmaktır. İnatçı kişi ancak zaman içerisinde inadının yanlış netice verdiğini gördüğünde pişmanlık duymaktadır. Kur'an'da Firavun'un inadından dolayı pişmanlığı anlatılmaktadır. ${ }^{4}$ Sözlükte "muhalefet etmek, yoldan çıkmak, haktan sapmak" olarak tanımlanan" inat" kavramı, "kişinin bildiği halde bir şeyden yüz çevirmesi, ondan sapması" 45 şeklinde tarif edilmektedir. Kur'an'da inatçı "gerçeği kabul etmekte direnen isyankâr kişi" anlamına gelmektedir. Aynı zamanda bu kavram inkâr ve şirk kavramlarıyla ilişkili olarak kullanılmaktadır. ${ }^{46}$ Bireyin yanlış düşünce ve eylemlerinde inat etmesi hakikate karşı kapılarını kapatmasıdır. İnat etmek bir konudaki yanlış bilindiği halde o konuda muhalefet ederek yola devam etme gayretini ifade etmektedir. Yanlış tasavvur ve yanlış eylemlerde inat etmenin sonucunda pişmanlık tecrübesi yaşanmaktadir.

\section{Cimrilik veya İsraftan Duyulacak Pişmanlık}

İnsana pişmanlık tecrübesi yaşatan ilginç olumsuz davranışlardan biri cimrilik, diğeri de israftır. Cimri sözcüğü Farsça “soysuz, alçak, adi, dilenci, kimseye bir şey vermek istemeyen" manasına gelmekle beraber "pintilik, hasislik" anlamında kullanılmaktadır. Cimrilik kavramı "Servet edinme

41 Zemahşerî, Keşşâf Tefsiri, 2, 420; Razî, Tefsirü'l-Kebir, IX, 34-35.

42 Ebu Mansur el- Mâtürîdî, Te'vilatül Kur'an Tercümesi, çev. Kemal Sandıkçı (İstanbul: Ensar Neşriyat, 2017), IV, 213.

43 Razî, Tefsirü'l-Kebir, IX, 35-37.

44 Zâriyât, 51/38-40; Elmalılı Muhammed Hamdi, Hak Dini Kur'an Dili (İstanbul: Matbaai Ebuzziya, 1935), VI, 4539.

45 Rağıp el-İsfahanî, Müfredatu Elfazi'l-Kur'an, thk: Safvab Adnan Davudi (Dımaşk: Darü'1-Kalem, Beyrut: Darü'ş-Şamiyye, 2002), “inad", 590.

46 Mustafa Çağrıcı, "İnat", Türkiye Diyanet Vakfi İslâm Ansiklopedisi, (Ankara: TDV Yayınları, 1993), XXII, 264265. 
tutkusuyla karşılıksız harcamadan ve hayır yapmaktan kaçınma eğilimi" olarak tanımlanmaktadır. ${ }^{47}$ İsraf ise, Arapçadan Türkçeye geçmiş "haddi aşma, gaflet, hata, cehalet" anlamlarına gelmektedir. İslam literatüründe "insanın yapmış olduğu her fiilde haddi aşması" olarak tarif edilmektedir. ${ }^{48} \mathrm{Bu}$ kavram Kur'an'da ölçüsüzlük ve aşırılık anlamında kullanılmaktadır. Tasavvurda ve eylemde ölçü bilmemek insanı küfre kadar götürebilecek bir durumdur. İsraf kavramı, Kur'an'da müşrik ve kâfirlerin özellikleri olarak kullanılmaktadır. Firavunun müsrif olması ilahlık iddiasına gidecek kadar ölçüsüz olmasıyla ilişkilendirilmektedir. ${ }^{49}$ Kur'an'da Allah'ın verdiği nimetlerde cimrilik yapmak ne kadar yerilmekteyse, o nimetleri israf etmek o derece yerilmektedir. Kur'an'da müsrifler ve cimriler sevilmeyen kişiler olarak tanımlanmakta, Rahman'ın kullarının israf etmeyen, aynı zamanda cimri de olmayıp ölçülü davranan kişiler oldukları ifade edilmektedir. ${ }^{50}$ Netice itibariyle canlılı̆̆1 durduracak kadar cimri olmak ve ekonomik sermayeyi tüketecek kadar müsrif olmak dengeleri bozan bir durumlardır. Ekonomik canlılığın durması veya israf kültürünün hükmettiği bir ekonomik sistem hem bireysel anlamda hem de toplumsal anlamda çöküşe, bu çöküş de kaçınılmaz bir pişmanlık yaşanmasına neden olmaktadır.

\section{Nimetlere Ebedilik Atfetmekten Duyulan Pişmanlık}

Tasavvurunu vahiyle inşa etmeyen, nimete ebedilik atfedenler için pişmanlık tecrübesi kaçınılmazdır. Kur'an'da bu konu iki arkadaşın misaliyle açıklanmaktadır. ${ }^{51}$ Kendisini servetçe, nüfusça güçlü görüp kendisine verilen nimetlerin elinden hiç gitmeyeceğini düşünerek davranan, arkadaşının varlıklarını az görerek küçümseyen bir kişinin sahip oldukları elinden gittiği zaman yaşadı̆̆ı pişmanlık anlatılmaktadır. ${ }^{52}$ Ayrıca servetine ebedilik atfeden Karun'un kıssası da iki arkadaşın kıssasına benzer mesajlar vermektedir. Karun, servetin sahibi olmaya layık olduğu için çok zengin olduğunu düşünen biridir. Karun'un dünya malını ebedi olarak görmesiyle imtihanı başlamaktadır. Ayetler Karun'un servet perspektifinin yanlışlığını ve sonunda düştüğü içler acısı durumu bir film gibi gözler önüne

\footnotetext{
Mustafa Çağrıcı, "Cimrilik", Türkiye Diyanet Vakfi İslâm Ansiklopedisi, (Ankara: TDV Yayınları, 1993), VII, 4.

48 İbn Manzur, Lisanü'1-Arab, “israf”, IX, 148; İsfahanî, “israf”, 407.

49 Yûnus, 10/83.

50 el-Furkân, 25/67; Zemahşerî, Keşşaf Tefsiri, IV, 890; Mâtürîdî, Te'vilatül Kur'an Tercümesi, X, 312.

51 el-Kehf,18/32-42.

52 Mâtürîdî, Te'vilatül Kur'an Tercümesi, IX, 78-84.
} 
sermekte, ${ }^{53}$ servet ve evlat çokluğuna sahip olduğu için kibirlenmesi ve sahip olduklarının gücüne güvenmesi sonucunda yaşadığı pişmanlık tecrübesi ve nimetlere ebedilik atfetmenin yanlışlığı ortaya konmaktadır. ${ }^{54}$ İnsan varlı̆̆ 1 servet, makam, çocuk gibi dünya nimetleri nedeniyle kendini güçlü görebilmektedir. Kur'an açık bir şekilde dünya nimetlerinin dünya hayatının geçici imkân ve süsleri olduğunu bildirmektedir. ${ }^{55}$ Kişi Allah'ın verdiği nimeti kalıcı görüp, elindeki nimetlerin asıl kaynağını unutarak her nimeti "benim" gözlüğüyle görmeye başladığında egosunu büyütmeye başlamaktadır. Egosu büyüyen, kendisi küçülen kişi Allah'ın "bak" dediği yerden bakmadığı için elindeki nimetlere bağımlı bir hale gelmektedir. Bu bağımlılık nimetin elden gitmesine yönelik korkular ve kaygılar oluşturmaktadır. Vahiy insanın servetle ilişkisini doğru bir tasavvur üzerine inşa etmesini istemekte, böylelikle pişmanlı yaşamasının önüne geçmektedir.

\section{Allah'ı Dikkate Almadan Yapılan Planın Getireceği Pişmanlık}

Kur'an, müminin bir iş yapmaya karar verirken ve işe başlarken "inşallah" (Allah dilerse) ${ }^{56}$ demesini tavsiye etmekte ve "biiznillah" yani Allah'ın izni olmadan bir eylemin gerçekleşemeyeceğini ${ }^{57}$ bildirmektedir. "Allah dilerse" demek yapılacak işe ya da plana Allah'ın müdahil olmasını istemektir. Bu ifadeleri kullanmadan bir işe teşebbüs etmek Allah'ı o işe katmamaktır. Vahiy Allah'ın müdahalesinin olmadığı bir planın pişmanlık yaşatacağını bildirmektedir. ${ }^{58}$ Kur'an'da Allah'a iman etmiş, hurma bahçeleri, ziraata elverişli arazileri olan zengin aynı zamanda malından, mülkünden ihtiyaç sahiplerine cömertçe tasadduk eden bir kişiden bahsedilmektedir. Adam ölünce malına, mülküne çocukları varis olurlar ve babaları gibi tasadduk etmek istemezler. Ortanca kardeşleri itiraz etse de fakire fukaraya mahsullerinden vermeme kararı alırlar. Allah'tan bağımsız bir plan yaparak bir sabah erkenden fakir fukara duymadan, gizlice bahçenin tüm ürününü toplamak için yola çıarlar. Amaçlarına ulaşacaklarından emin bir şekilde bahçelerine girerler. Bahçelerini yanmış, simsiyah bir halde görünce "Herhalde biz yanlış yere geldik" derler.

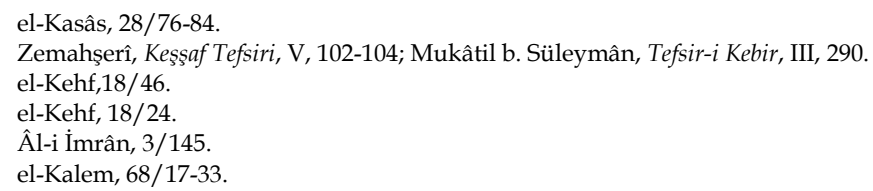


Bahçedeki tüm ürünler yanıp kül olduğu için hayalini kurdukları mahsulden hiçbir şey elde edemezler. ${ }^{59}$ Dolayısıyla Allah'tan bağımsız planların sonucunda pişmanlık yaşanacağı anlaşılmaktadır.

\section{Araştırmadan Verilen Karardan Duyulan Pişmanlık}

Bireysel ya da toplumsal olarak alınan haberler araştırılmalı, güvenilir kaynaklara itibar edilmelidir. Aksi takdirde yalan, yanlış haberler hem bireye hem de topluma büyük zararlar vermektedir. Bireysel ya da toplumsal pişmanlıklara zemin hazırlamamak için haberin kaynağının araştırılması gerekmektedir. ${ }^{60} \mathrm{Kur}^{\prime}$ an herhangi bir habere araştırılmadan itibar edilmemesini istemektedir.61 Dolayısıyla kişilerarası ve toplumlararası ilişkilerde araştırma yapmadan duyumlara göre tepkide bulunmak telafi edilmesi zor pişmanlıklara neden olacağı görülmektedir.

\section{Helak Olma Durumu Yaşayan Toplumların Pişmanlığı}

Bireysel olarak yaşanan pişmanlıklar gibi toplumsal olarak yaşanan pişmanlıklar da bulunmaktadır. Kur'an'da tövbe etmeyen toplulukların sonlarının helak olacağı belirtilmekte, Yûnus kavminin tövbesinin bir toplumu nasıl helak olmaktan kurtardığı anlatılmaktadır. İman etmeyip yaptıkları yanlış eylemlerden geri dönmeyen toplumların yaşadığı pişmanlıklar anlatılarak ${ }^{62}$ toplumsal değişim istenmektedir. Kur'an'da toplumsal bir imandan bahsedilmektedir. Toplumsal akıl gibi toplumsal bir imandan bahsetmek mümkündür. Kur'an geçmişte yaşamış olan her toplumun iman etme iradesi ellerindeyken sürekli erteleyerek iman etmemeleri ve kendilerine gelen peygamberlere olumsuz tepkiler vererek menfi bir duruş sergilediklerini bildirmektedir. Toplumların bu olumsuz tepkilerinin helak olmalarına neden olduğu, akıllarını ve sağduyularını kullanarak kendilerini refaha götürecek gerekli değişimi yapmadıkları pişman oldukları ama Yunus Peygamber'in kavminin pişman olup tövbe ederek değişime gittikleri anlatılmaktadır. ${ }^{63}$ Netice itibariyle pişmanlık birey bazında yaşandığı gibi toplumsal olarak da yaşanan bir tecrübedir. Şayet bir toplum Yunus Peygamberin toplumu gibi yanlışlarından pişman olup o

\footnotetext{
Razî, Tefsirü'l-Kebir, XXII, 54-59; Yazır, Hak Dini Kur'an Dili, VII, 5278-5284.

60 Mâtürîdî, Te'vilatül Kur'an Tercümesi, C.14, s. 79; Bayraklı, Yeni Bir Anlayışın Işı̆̆ı̆nda Kur'an Tefsiri, VIII, 169.

61 el-Hucurât, $49 / 6$.

62 Yûnus, 10/98.

63 Zemahşerî, Keşşaf Tefsiri, III, 342. Bayraktar Bayraklı Yeni Bir Anlayışın Işı̆̆ında Kur'an Tefsiri, IX, 83.
} 
yanlışlardan dönebilme iradesini kullanabilirse o toplumun toplumsal çöküşten kurtulabileceği anlaşılmaktadır.

\section{Başkası İçin Duyulan Pişmanlık}

Müslüman toplumsal sorumluluğu olan ve toplumuna karşı duyarlı davranan kişidir. Kur'an'da bu duyarlılığın zirvede anlatıldığı bir kıssa bulunmaktadır. Yasin suresinde anlatılan bu kıssada sadece kendisini değil toplumunun akıbetini de düşünen bir kişiden bahsedilmektedir. ${ }^{64} \mathrm{Bu}$ ayetlerde anlatılan kişinin çok değerli bir kişi olduğu vurgulanmakta, peygamberlerin tebliğ ettiği dine inandığı ve tebliğlerini desteklediği bildirilmektedir. Onun bu duruşu hakikate olan inancının göstergesidir. İnandığı davadan asla vazgeçmediği, toplumu kendisine eziyet ettiği halde onlar için üzüldüğü ve onlar adına pişmanlık duyduğu anlatılmaktadır. ${ }^{65}$ Bireyin toplumu adına pişmanlık duyması ve toplumu için hayır duada bulunması prososyal yani diğerkam bir davranış biçimidir. Başka bir ifadeyle, kişinin kendisini düşünmeden diğerkamlıkla toplumunun hayrı için hareket etmesidir. Dolayısıyla bireyin başkası ya da toplumu adına pişmanlık duyması o kişilerin hayrına çaba göstermesidir.

\section{Ahiretteki Pişmanlıklar}

Kur'an pişmanlığın dünyada yaşanacağı gibi ahirette de yaşanacağını bildirmektedir. Dünyadaki pişmanlıklar birey veya toplumların hayatlarında bir değişim ve dönüşüm meydana getirmesine imkân tanımaktadır. Kur'an ahirette yaşanacak pişmanlıkların ise fayda vermeyeceğini bildirmektedir.

\section{Allah'a Şirk Koşmaktan Duyulacak Pişmanlık}

Kur'an dünyada şirk koşanların ahirette nedamet duyacaklarını ve bu pişmanlıkların kendilerine bir yararı olmayacağını bildirmektedir. Şirk iki malın birbirine karıştırılması, maddi veya manevi bir şeyin iki ya da daha fazla kişiye ait olması anlamına gelen "ş-r-k" kökünden gelmektedir. ${ }^{66}$ Kur'an'da şirk, Allah'a kudretinde ve sıfatlarında ortak koşmak anlamında kullanılmakta, şirkin kökeninde insanların nefislerinin isteklerine, heva ve heveslerine uyarak tevhit inanışına karşı başkaldırmalarının bulunduğu

\footnotetext{
Yâsîn, 36/13-32.

65 Zemahşerî, Keşşâf Tefsiri, V, 624-626; Mâtürîdî, Te'vilatül Kur'an Tercümesi, XII, 87-90.

66 İsfahanî, "şirk", 451.
} 
vurgulanmaktadır. ${ }^{67}$ Kur'an, şirkin kulun Allah'ın kendisine yeteceğini bilmemesinden kaynakladığını belirtmektedir. ${ }^{68}$ Şirk insanın Allah'ı yetersiz görüp, kendisine yararı ya da zararı olamayan sahte tanrılar üretmesi ve o tanrılardan korkarak davranışlarını şekillendirmesidir. ${ }^{69} \mathrm{Bu}$ uydurma tanrılar sadece insanın zihninde oluşturduğu bir birtakım kuruntulardır. Dolayısıyla şirk yoktan var eden, yarattıklarının her birinin ihtiyacını gören Allah'a "yetersizlik" isnat etmektir. 70 Günümüzde modern hayatın sahnesinde somut varlıklardan soyut düşüncelere, akımlara, ideolojilere kadar tanrılaştırılmış birçok put çeşidi rol almaktadır. Mümin Allah'ın kendisine şah damarından yakın olduğunu ${ }^{71}$ bilmeli ve kendisine herkesten, her şeyden çok yakın ve kudreti sonsuz bir Rabbi olduğunu hatırlayarak şirk inancından uzak durmalıdır. Aksi taktirde şirk inancı dünyada kişinin kendi öz varlığından uzaklaşmasına, ahirette ise öz varlığını pişmanlıkla tüketmesine neden olacaktır.

\section{Allah'a ve Peygamberine İtaatsizlikten Duyulacak Pişmanlık}

Ahirette yaşanacak geri dönüşü olmayan pişmanlıklardan biri de Allah'a ve peygamberine itaatsizlikten duyulacak pişmanlıktır. İtaat kavramı Arapça "tav" kökünden türemiş olup baş eğmek, emredileni yerine getirmek, belirlenen bir şeyin peşinden gitmek manalarına gelmektedir. ${ }^{72}$ Günümüzde "itaat" kavramı sadece emre boyun eğme anlamında kullanılmaktayken, Kur'an'da gönülden uyma, gönülden boyun eğme, kabul etme, söz dinleme, isteyerek yapma, gönülden hayır ve iyilik yapma anlamlarında kullanılmaktadır. İtaatin içinde gönüllülük esası da bulunmaktadır. İtaatin en güzeli gönülden olandır. Bunun en güzel örneği Hz. Peygamber'in itaat konusundaki tutumudur. Hz. Peygamber Allah'ın emir ve yasaklarını tebliğ etmiş, kimseyi inanması için zorlamamış, kimseden hesap da sormamıştır. 73 İtaat konusundaki ayetler değerlendirildiğinde itaatin şuursuzca ya da bilinçsizce yapılması istenmemekte Allah ve resulünün çağrısının iyi bir şekilde anlaşılarak ve

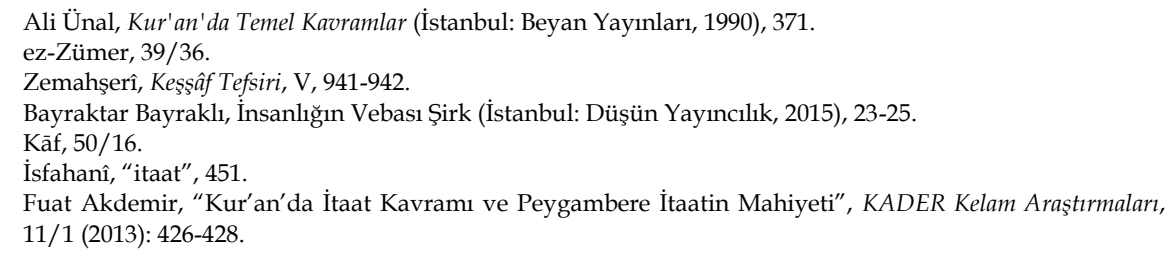


mesajın gerçek manası kavranarak yapılması istenmektedir. ${ }^{74}$ Allah'a ve peygamberine itaatin önemini anlatan birçok ayet bulunmakta, ${ }^{75}$ Allah'a ve peygambere tabi olmayanların ahirette pişman olacakları ifade edilmekte, bu tutumlarından vazgeçmeleri istenmektedir. ${ }^{76}$

\section{Allah'ın Ayetlerini İnkâr ve Yalanlamaktan Duyulacak Pişmanlık}

İmanın zıddı olan küfür kelimesi, örtmek, örtbas etmek, üstünü kapamak anlamlarına gelmektedir. ${ }^{77}$ Arapçada insanları gizlediği için geceye ve tohumu toprağa gömen çiftçiye 'kâfir' denilmektedir. Küfür, inançta imanın zıddı olan inkâr; amelde ise şükrün zıddı olan nankörlüktür. Nimetleri görmemezlikten gelmek de küfran-1 nimet olarak tanımlanmaktadır. ${ }^{78}$ Tohumu toprağa gömmek gibi Allah'a ait hakikatlerin üstünü örtmek de bir nevi o hakikatleri gömmek, üstlerini kapatmaktır. Bir başka ifadeyle Allah'a ait hakikatlerin üstünü batılla kapatmak, onları görmezden gelmek küfürdür. Aynı zamanda Allah'ın verdiği nimetleri yok saymak nankörlüktür. İnanmayanlar tarih boyunca çeşitli sebeplerle hakikati yalanlamışlardır, günümüzde de bu yalanlamalarını sürdürmektedirler. Hakikati inkârla ve yalanlayarak örtmeye çalışan kimseler akıllarını ve gönüllerini gerçeğe karşı kilitlemekte, inkâr ve hakikati hayat tarzı olarak benimsemektedirler. İnsanın süreklilik arz eden eylemleri inancını etkilemektedir. Kur'an'da inanmayanların inkâr merkezli tutumları ve tutumlarındaki değişmezlik nedeniyle Allah'ın kalplerine perde, kulaklarına gerçeği anlamalarına engel olacak ağırlıklar koyduğu bildirilmektedir. Böylece kalpleri hakikati görmemekte, kulakları ise hakikati duymamaktadır. ${ }^{79}$ Kur'an' da hakikate karşı sağır olanların, Allah'ın ayetlerini inkâr edenlerin ahirette derin bir pişmanlık yaşayacağı bildirilmektedir. ${ }^{80}$

\section{Doğru Yolda Olmamanın Pişmanlığı}

\footnotetext{
Ömer Mahir Alper, "İtaat”, Türkiye Diyanet Vakfi İslâm Ansiklopedisi, (Ankara: TDV Yayınları, 2001), XIII, 444. 
Ahirette insanın pişman olacağı eylemlerinden biri doğru yolda olmamaktır. Kur'an Allah'ın vahiy ve peygamberiyle insanlara öğrettiği şekilde yaşamayanların, doğru yolda olmayanların ahirette pişmanlık duygusuyla karşı karşıya kalacaklarını bildirmektedir. Doğru yolda olan kişi hakikat merkezli, doğru yolda olmayan kişi ise batıl merkezli bir hayat yaşamayı tercih etmektedir. Doğru yolda olmak Allah'a iman ve O'nun rızasına uygun bir yaşam ile mümkündür. Hidayet eksenli bir hayat tarzı doğru şekilde yaşanan bir hayattır. Bu hayat tarzı kişinin dünya hayatında saadete, ahirette kurtuluşa ermesinin yoludur. ${ }^{81}$ Kur'an dünyada doğru yolda olmayanların, batıl uğruna ömürlerini geçirenlerin ahiret gününde dönüşü olmayan bir pişmanlık ve elem verici bir azap yaşayacaklarını haber vermektedir. ${ }^{82}$

\section{Kur'an'ın İnanmayanlar İçin Pişmanlık Kaynağı Olması}

Kur'an Allah'ın göklerden insana indirdiği, akla ve gönle hitap eden, Allah ile kul arasında ilahi bir iletişimdir. Aynı zamanda insanların hayat tarzlarını doğruya yönlendirmek için hidayet rehberi olarak indirilmiştir. Kur'an'ın koymuş olduğu prensipler, anlattığ tarihi olaylar, peygamber kıssaları öğüt ve ibret alınacak derslerdir. Allah'tan korkan, sorumluluk bilinci olan kişiler Kur'an hakikatlerine akıllarını ve kalplerini açmaya çalışmaktadırlar. Buna mukabil akıllarını ve kalplerini hakikate kapatanlar gaflet içinde yaşamaları nedeniyle öğütlere ve nasihatlere kapılarını açmamakta, Allah'ın kitabından istifade etmemektedirler. Allah'a inananlar ise bu kitabın içinde bilgi, sevinç ve hayat bulmaktadırlar. ${ }^{83} \mathrm{Kur}^{\prime} \mathrm{an}^{\prime} \mathrm{da}$ inanmayanların ilahi mesajı yalandıkları ve bu kimselerin ahiret gününde pişman olacakları bildirilmektedir. ${ }^{84}$ Dolayısıyla ahiret gününde Kur'an'ın kendisine uyan ve muhtevasıyla amel edenler için bir ödül olacağı, ona inanmayanlar için iç yangını olacağı anlaşılmaktadır. 85

\section{Ahireti İnkâr Etmekten Duyulacak Pişmanlık}

Kur'an tevhit, nübüvvet ve ahiret olmak üzere üç ana konu üzerine inşa edilmektedir. Vahiy insanı öncelikle Allah'ın birliğine iman etmeye davet ederek şirkin ve küfrün geçersizliğini anlatmaktadır. İkinci önemli

\footnotetext{
1 Enes Yariz, “Kur'an'a Göre Hidâyete Ermede İnsanın Rolü”, İ.Ü. İlahiyat Fakültesi Dergisi, 8/2 (2017): 364. 2 el-Kasâs, 28/ 64; Mâtürîdî, Te'vilatül Kur'an Tercümesi, XI, 80-81.

33 Seyyid Kutup, Fî Zilâli'l-Kur'ân, çev. Bekir Karlığa v.dğr. (İstanbul: Hikmet Yayınevi, 1970), XV, 213.

84 Hâkka, 69/48-50.

85 Mâtürîdî, Te'vilatül Kur'an Tercümesi, XVI, 87.
} 
husus olarak ahirete iman konusu üzerinde durulmaktadır. Kur'an'ın "Allah'a ve ahiret gününe iman" konusunu birlikte ele alması ahirete imanin ne derece önemli olduğunu göstermektedir. ${ }^{86}$ Kur'an'da neredeyse her surede ölüm ötesi hayattan bahsedilmekte ve zihinlerde ahiret tasavvuru inşa edilmeye çalışılmaktadır. Kur'an'da Allah'a imanla birlikte ifade edilen iman esaslarından biri olan ahirete iman, kişide yaptığ vereceğinin bilincini oluşturmaktadır. Ahiret bilinci bireyin söylem ve eylemlerini kontrol altında tutmasında özdenetim mekanizması çalıştıran bir esastır. Kur'an ahiretin dünya hayatından hayırlı olduğunu, ${ }^{87}$ ahirete iman etmeyen kişilerin sonlu mutlulukları elde etmek için ömürlerini harcadıklarını, hayatlarının sonuna geldiklerinde ellerinde hiçbir kazanç kalmayacağını açıklamakta ve ahiret gününde geri dönüşü olmayan bir pişmanlığın acısını tadacaklarını bildirmektedir. ${ }^{88}$

\section{Salih Ameller İşlememekten Dolayı Yaşanacak Pişmanlık}

İmanın aksiyonu olan amel imanın davranışsal boyutudur. Sözlüklerde amel, eylem, çalışma anlamına gelmekte, ${ }^{89}$ canlılardan isteğe bağlı olarak meydana gelen her fiil olarak tanımlanmaktadır. ${ }^{90}$ İmanın gerekli kıldığı amel kişiye, çevresine, insanlığa faydası olan salih amelleri ifade etmektedir. Salih amel kavramı sadece namaz kılmak, oruç tutmak, haccetmek gibi ibadetleri ifade etmemektedir. Bu ibadetler salih amel için bir cüzdür ama salih amelin tamamı değildir. Kur'an'da salih amelle ilgili ayetler değerlendirildiğinde salih amelin kapsamının çok geniş olduğu anlaşılmaktadır. Dolayısıyla Allah'ın rızasını kazanmak amacıyla ilahi emirleri yerine getirmek, insanlığın faydasına iyilikler, güzellikler yapmaktır. ${ }^{91}$ Kur'an'da ahiret gününde salih amel işlemeyenlerin pişman olacakları bildirilerek insanlar salih amel işlemeye davet edilmektedir. ${ }^{92}$

\section{Allah Yolundan Çevirmeye Çalışanların Pişmanlığı}

Nefislerinin kölesi olan kimseler sadece kendileri hakikate karşı kör ve sağır olmakla kalmayıp hayatlarını doğru bir şekilde tanzim etmeye

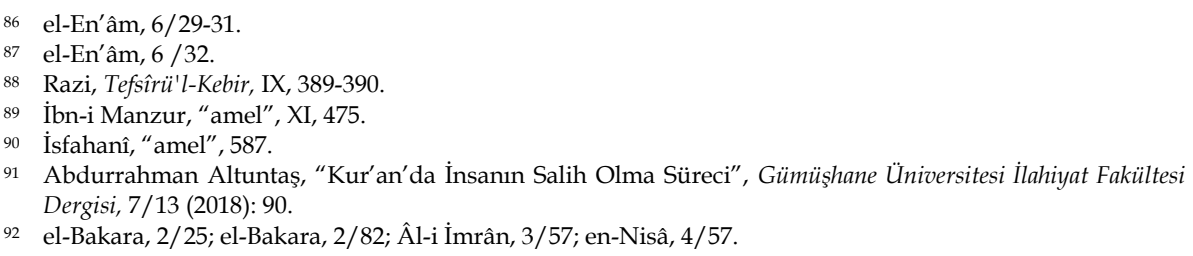


çalışan kimseleri de kendilerine benzetmeye ve doğru yolda yürümelerine engel olmaya çalışmaktadırlar. Kendilerini çıkmaza sürükleyen küfür eylemlerine çevrelerindeki kişilerin de dahil olmasını istemektedirler. $\mathrm{Bu}$ kısır anlayışa sahip olan kişiler, toplumlarını Hakk'a imandan menederek bu eylemlerinin hayırlı olduğunu düşünmektedirler. Fakat hakikate karşı yaptıkları olumsuz eylemleri sadece kendileri için pişmanlık olarak sonuçlanmaktadır. ${ }^{93} \mathrm{~Hz}$. Peygamber döneminde, müşriklerin müminlerin Allah yolunda olmalarını engellemek için güçlerini bir araya getirip ortak ekonomik güç birliği oluşturdukları, bu ortak ekonomik güç sayesinde daha büyük eylemler yapabilme imkanları bularak insanları Allah'ın yolundan engellemeye çalıştıkları ama hüsrana uğradıkları tarihsel bir gerçekliktir. ${ }^{94}$ Kur'an çok açık bir şekilde insanları Allah yolundan alıkoymak için çalışanların cezasının pişmanlık olacağını ve o pişmanlığın bir iç yangını olarak ortaya çıkacağını bildirmektedir..$^{95}$

\section{Yanlış Önderlere Tabi Olmaktan Dolayı Duyulacak Pişmanlık}

İnsanı ahirette geri dönüşü olmayan bir pişmanlıkla karşı karşıya bırakacak eylemlerden biri de yanlış liderlere tabi olmaktır. Kur'an aklını yanlış liderlere kurban edenlerin ahirette akıllarını kullanmadıkları için pişman olacaklarını ama bu pişmanlığın fayda vermeyeceğini bildirmektedir. ${ }^{96}$ Dünyada akıllarını kullanmadan peşlerinden gittikleri kişilerle ahiret gününde münasebetlerinin kesileceği ve tabi oldukları liderlerin kendilerini dahi kurtaramayacağını gördüklerinde hakikati anlayacakları anlatılmaktadır. Yanlış liderlere tabi oldukları için pişman olacakları, dünya hayatındayken onlardan uzaklaşmadıkları için çok üzülecekleri ve ahiret günü aralarında büyük bir husumet yaşanacağı haber

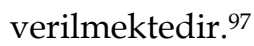

\section{Allah'ı Anmaktan Gafil Olmanın Pişmanlığı}

Allah'ı anmak O'na kulluğun en önemli emarelerinden biridir. Kulluk bilinci Allah'ı anmak ve ilahi mesajını anlama etkinliğiyle gelişim göstermektedir. Allah'1 anmaktan gafil olmak kişinin dünyevileşmesine neden olmaktadır. Allah'tan gafil olma ve gafil bir şekilde yaşama talebi

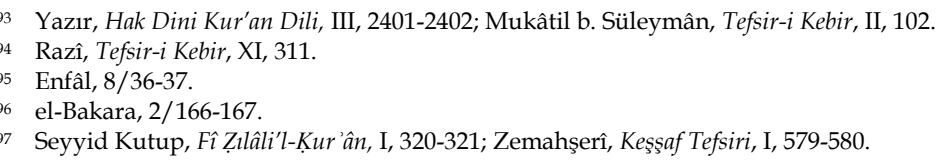


ahirette pişman olmak anlamına gelmektedir. ${ }^{98}$ Allah'ın zikrinden gafil olmak öncelikle Allah'1 hatırlamamak, O'nun varlığını kabul etmemek ve Allah'tan bağımsız bir hayatı tercih etmek, ${ }^{99}$ ikinci olarak Allah'1n vahyine ya da dinine inanmadan yaşamaktır. Bu tutum kişiyi Allah'tan uzaklaştırıp şeytani bir yol izlemesine ve şeytani ya da dünyevileşmiş davranışlara yönelmesine neden olmaktadır. ${ }^{100}$ Dolayısıyla Allah'1 anmaktan gafil olmak bireyi dünyevileştirmekte ve Rabbine uzaklaştırmaktadır. Ahiret gününde Allah'tan gafil olmanın getirisinin pişmanlık olacağı anlaşılmaktadır.

\section{Yanlış Dost Edinmekten Duyulacak Pişmanlık}

İnsan varlığı fıtratı gereği sosyal ilişkiler kurarak hayat yolculuğuna devam etmektedir. İnsan için iletişim kurabileceği, güven duyabileceği, ortak inanca sahip kişilerle dost olmak hayat yolculuğunda önemlidir. Dostluk sevilen kişiyi kalpte tutmak aynı zamanda sevilen kişiye tutunmak, onu hatırda tutmak ve onun hatırını tutmaktır. ${ }^{101}$ Dostluk duygusu çoğunlukla kişiye huzur verirken bazen kişinin düzenini bozup huzursuzluk da verebilmektedir. Kur'an yanlış seçilen dostların kişinin ahirette pişmanlığına sebep olacağını bildirmektedir. ${ }^{102}$ Kur'an'da geçen "yanlış dost" ifadesi Allah'ın zikrinden alıkoyan, peygamberin yolunda gitmeyi engelleyen ve dünyevileşmeye neden olan kimseler olarak yorumlanmaktadır. Ahiret gününde yanlış dost edinenlerin dostlarına uyarak büyük hatalar yaptıkları, Allah'a isyan ettikleri için çok büyük pişmanlık yaşayacakları belirtilmektedir. ${ }^{103}$

\section{Zalim Olmaktan Duyulacak Pişmanlık}

Zulüm karanlık, şirk, fısk anlamlarına gelmekte, bir şeyi kendisine ait olan yerin dışına koymak olarak tanımlanmaktadır. Bir şeyi kendisine ait yerin dişına koymak o şeyi eksiltmekle ya da fazlalaştırmakla meydana gelmektedir. Bir başka ifadeyle adaletten uzak, haksız davranmak zulümdür. Zulüm Allah ile kul, birey ile çevresi ve kişiyle nefsi olmak üzere üç kısımda değerlendirilmektedir. Kişinin Allah'a şirk koşması, çevresine ve kendi nefsine haksızlık yapması zulüm olarak kabul edilmektedir. ${ }^{104}$

\footnotetext{
98 ez-Zuhruf, 43/36-39.

99 Seyyid Kutup, Fî Zilâli'l-Kur'ân, XIII, 190-191

100 Mâtürîdî, Te'vilatül Kur'an Tercümesi, XIII, 267-268.

101 Kemal Sayar-Berna Yalaz, Ağ Sanal Dünyada Gerçek kalmak (İstanbul: Kapı Yayınları, 2019), 331.

102 el-Furkān, 25/27-29.

103 Seyyid Kutup, Fî Zilâli'l-Kur 'ân, X, 523-524; Mâtürîdî, Te'vilatül Kur'an Tercümesi, X, 279.

104 İsfahanî, “zulüm”, 537-538.
} 
Kur'an'da adaletten uzak olan zalimler için ahiret günü derin bir iç acısı olacağı bildirilmektedir. ${ }^{105} \mathrm{Kur}^{\prime}$ an' da zalim halkların ilahi buyrukları alay ve eğlenceye aldıkları, peygamberlerine zulüm edip onları öldürmeye kalktıkları, azap geldiğinde pişman olsalar da pişmanlıklarının fayda vermediği ifade edilmektedir. ${ }^{106}$ Netice itibariyle zulüm öncelikle Allah'ın buyruklarına isyan etmek sonrasında ölçü tanımayıp kullara zalim olmaktır. Ahirette zalim olmanın sonucunda dönüşü olmayan bir pişmanlık yaşanacağı anlaşılmaktadır.

Sonuç olarak Kur'an'da dünya ve ahirette yaşanacak pişmanlıklar anlatılmakta, ilahi eğitim gereği Allah dünya ve ahirette pişmanlık getirecek eylemleri ve bu eylemlerin alt yapısını oluşturan yanlış tasavvurları vahiyle bildirmektedir. Dünya ve ahirette kullarının pişmanlık yaşamaması için tasavvur ve eylemin nasıl doğru inşa edilebileceğini göstermektedir. Kur'an Allah'ın istediği gibi bir hayat yaşamayanların ahirette pişmanlıklarının geri dönüşü olmayacağını açılamaktadır.

\section{E. Ahirette Pişman Olan Kimselerin Talepleri}

Kur'an insanlara doğru ve yanlış eylemleri anlatıp, karşllı̆ıında kazanılacak ödül ya da cezayı da haber vermektedir. Aynı zamanda dünyada ve ahirette kimlerin hangi eylemleri nedeniyle pişmanlık yaşayacağını bildirmekte ve bu eylemlerden uzak durulmasını istemektedir. Kur'an ahiret gününde pişmanlık yaşayanların bazı talepleri olacağı ama onların bu taleplerinin kabul edilmeyeceğini bildirmektedir. Dolayısıyla ahirette pişmanlığın yaşandığı gün arzular, seçenekler, tercihler anlamını kaybetmiş olacaktır.

\section{Pişmanlık Duyan Kimselerin Dünyaya Geri Dönmeyi İstemeleri}

Kur'an ahirette yanlış eylemleriyle yüzleşen kişilerin pişman olup birtakım taleplerde bulunacaklarını ama o taleplerin geri çevrileceğini haber vermektedir. ${ }^{107}$ Allah vahyinde bu kimselerin yalancı olduklarını, değişmeyeceklerini bildirmektedir. ${ }^{108}$ Çünkü içine düştükleri sıkıntı nedeniyle dünyaya döndüklerinde iman edeceklerini söylemektedirler.

\footnotetext{
105 el-Enbiyâ, 21/11-15.

106 Zemahşerî, Keşşaf Tefsiri, IV, 408; Seyyid Kutup, Fî Zulâli'l-Kur 'ân, X, 114-115.

107 el-En'âm, 6/27.

108 İbrâhîm,14/44.
} 
Hâlbuki olumlu ya da olumsuz davranışlar süreklilik arz ettikçe insanda sağlam karaktere dönüşmektedir. Şayet kişi yaptığı hatadan yaşadığı bir korku nedeniyle pişman oluyorsa süreç normalleştiğinde hatalı da olsa aynı eylemleri yapmaya devam etmekte 1 srarc1 olabilmektedir. Dolayısıla ahirette pişmanlık yaşayıp dünyaya geri dönme talebinde bulunan kişilerin dünyaya döndüklerinde aynı eylemleri gerçekleştirebilme olasılıkları yüksektir. Kur'an bu kişilerin taleplerinin kabul edilmeyeceğini belirtmektedir. ${ }^{109}$

\section{Hesap Gününde Amel Defterlerini Almak İstememeleri}

Kur'an her kelimenin, her cümlenin, her eylemin teke tek hesabının verileceği günün muhakkak geleceğini bildirmektedir. ${ }^{110}$ Hesabı hesaba katmadan yaşayanlar bütün hesapların görüleceği günde derin bir iç acısı yaşayacaklardır. Ahiret gününde insanlar dünyada hangi eylemleri gerçekleştirdiklerini bilseler de o eylemlerin iç yüzünü, değerlendirilmesini istemeyeceklerdir. Yapılan bütün eylemler bilgisayarda hesaplanmış gibi detaylı bir şekilde insanların önüne konulduğunda kazanç beklerken kaybettiğini gören kimselerin amel defterlerini almak istemeyecekleri belirtilmektedir. ${ }^{111}$ Amel defterlerinin sol taraftan verilmesi sonucun kötü olduğunu işaret etmektedir. Kişi dünyada zannının ve beklentisinin aksinin olduğunu fark edince amel defterini almak, yaptığı eylemlerin sonuçlarıyla karşılaşmak istemeyecektir. Ancak bu talepleri kabul edilmeyecektir. ${ }^{112}$

\section{3. Ölümün Bir Son Olmasını ve Daha Önce Hiç Yaşamamış Olmayı İstemeleri}

Kur'an öldükten sonra her şeyin biteceğini, ahiret hayatının olmayacağını iddia edenlerin yaptıklarının hesabını vereceklerini anlayacaklarını ve yok olmayı temenni edeceklerini haber vermektedir. Her yaptığı söylemin ve eylemin hesabıyla yüzleşecek kişinin, ölümü kendisi için son çare olarak göreceği ve yok olmayı isteyeceği çaresizliği tasvir edilmektedir. ${ }^{113}$ Ayette geçen "Keşke ölüm her şeyi bitirmiş olsaydı!" ifadesi sadece geçmişte yaşananlardan ötürü duyulan bir pişmanlık değildir. Aynı zamanda kendisini çıkmazda gören bir kişinin ölümü bir kurtuluş olarak

\footnotetext{
109 Zemahşerî, Keşşâf Tefsiri, II, 624-626; Seyyid Kutup, Fî Zilâli'l-Kur ân, III, 152.

110 Meryem, 19/95.

111 el-Hâkka, 69/25-26

112 Mâtürîdî, Te'vilatül Kur'an Tercümesi, XVI, 79-80.

113 el-Hâkka, 69/27.
} 
görmesidir. ${ }^{114}$ Hayata ve olaylara ilahi mesajın bak dediği yerden bakmayanlar fani olan varlığı baki olarak görmektedirler. Ecel-i müsemma geldiğinde, uyarıları uyarı kabul etmeyenler amel defterlerini ellerine aldıklarında dünyada yaptıklarını, önceden gönderdiklerini göreceklerdir. Kur'an kurtuluş için bir çıkış kapısı olmadığını gören kimselerin pişmanlığın yoğun atmosferini yaşayacaklarını, derin bir iç acısı ve mahcubiyetle toprak olmayı, yokluğa gömülmeyi isteyeceklerini bildirmektedir. ${ }^{115}$ Ayette geçen "keşke toprak olsaydım" ifadesi dünyada iken mükellef bir varlık olmama ya da hesap için diriltilmeyip yok olmayı talep olarak yorumlanmaktadır. ${ }^{116}$

Netice itibariyle dünyada aklını kullanmayıp Allah'ın dinine tabi olmayanlar, peygamberlerin uyarısını hiçe sayanlar ahiret gününde kendileriyle yüzleşeceklerdir. Herkesin niyet ve eylemleri objektif bir zeminde değerlendirilecek ve sonuçlar ellerine verilecektir. İyi amel işleyenler için cennet ödül olurken, kötü ameller için karşılık cehennem olacaktır. Eline amel defterini alan ve değerlendirme sonucunu gören kişi hatalarından, isyanlarından nadim olacaktır. Bütün kurtuluş çarelerinin bittiğini anlayan kişi, son bir ümitle bazı taleplerde bulunacaktır. Fakat o gün talepler kabul görmeyecektir. İnsana eylemlerini değiştirme ve dönüştürme için fırsat verilen yer dünyadır. Kur'an değerlendirme alanı olan ahirette değişim ve dönüşüm için bir fırsat daha verilmeyeceğini, tüm taleplerin reddedileceğini bildirmektedir.

\section{F. Peygamberlerin Pişmanlıkları ve Tövbeleri}

Peygamberler insanın varoluşsal gerçeğiyle aynılığı olan ilahi kaynaklı eğitimcilerdir. Tasavvur ve eylem inşasında hem teoriyi anlatan hem de teoriyi uygulama alanına yansıtan peygamberlerin yanlış eylemleri ve tövbeyle aktive ettikleri pişmanlık tecrübeleri yanlış eylemi düzeltme ve düzenleme anlamında prototip oluşturmaktadır. Pişman olmak peygamberler dâhil her mevkiden, her seviyeden insanın yüzleştiği bir duygudur. Allah Kur'an'da peygamberlerinin pişman oldukları eylemleri ve pişmanlıklarını dile getirdikleri tövbelerini zikretmektedir. Bu durum insan için bir imkandır. İlk insan ilk peygamberle insanlığın serüveninde yerini alan pişmanlık tecrübesi insan varlığı devam ettiği müddetçe var olmaya devam edecektir. Kur'an'da beş peygamberin pişmanlık tecrübesi ve

\footnotetext{
114 Yazır, Hak Dini Kur'an Dili, VII, 5332.

115 en-Nebe, 78/ 40.

116 Razî, Tefsirü'l-Kebir, XXII, 447; Yazır, Hak Dini Kur'an Dili, XII, 5549.
} 
tövbeleri anlatılmaktadır. Vahiy peygamber prototipleri üzerinden pişmanlık duygusunun nasıl aktif hale getirileceğini uygulamalı olarak gözler önüne sermektedir.

\section{1. Âdem Peygamberin Pişmanlığı ve Tövbesi}

İnsanlık tarihi kadar kadim bir tarihi olan pişmanlık duygusu ilk olarak insanoğlunun atası Hz. Âdem tarafından yaşanmış bir duygudur. Rol model olarak gönderilen peygamberlerin bu duyguyu yaşamaları ve tövbe ederek değişime gitmeleri insanlığa verilen bir eğitimdir. Hz. Âdem ve eşi cennette yaklaşmamaları gereken ağaca yaklaştıkları ve Allah'ın emrine uymadikları için tövbe etmişlerdir. ${ }^{117}$ Kur'an yeryüzüne inen ilk tövbe kelimelerinin Hz. Âdem ve eşine ait olduğunu bildirmektedir. ${ }^{118} \mathrm{~Hz}$. Âdem'in unutarak yediği yasak meyve nedeniyle günah işlediğini düşündüğü ve bu eylemi kendisine zulüm, Rabbine isyan olarak gördüğü anlaşılmaktadır. Hz. Âdem ve eşinin yaptıkları hata için Allah'tan af diledikleri ve kalıcı bir pişmanlık yaşamama niyazında bulundukları görülmektedir. ${ }^{119}$

\section{Nuh Peygamberin Pişmanlığı ve Tövbesi}

Kur'an'da Nuh Peygamber'in bilmediği bir konu hakkındaki talebinden pişman olup, yaptığı tövbe ettiği anlatılmaktadır. ${ }^{120} \mathrm{Nuh}$ Peygamberin oğlu inanmayanlardan olduğu halde Nuh Peygamber onu tufandan kurtarmak için gemiye davet etmiş ama oğlu bu daveti reddetmiştir. ${ }^{121}$ Nuh Peygamber oğlunun ailesinden olduğunu, kurtulmasını niyaz ettiğinde, Allah oğlunun onun ailesinden olmadığını, inanç yakınlığının soy yakınlığından önce geldiğini, bilmediği şeyi Allah'tan istememesi gerektiğini bildirince ${ }^{122}$ Nuh Peygamber böyle bir şeyi talep ettiği için tövbe etmiştir. ${ }^{123}$ Bilmediği şeyi istemekten Allah'a sığınmıştır. ${ }^{124}$ Böylelikle Nuh Peygamber işlemiş olduğu günahı bir daha

\footnotetext{
117 el-Bakara, 2/35-36.

118 el-A'râf, $7 / 23$

119 Mâtürîdî, Te'vilatül Kur'an Tercümesi, V, 340; Zemahşerî, Keşşâf Tefsiri, II, 826.

120 Hûd, $11 / 47$.

121 Hûd, 11/42-43.

122 Zemahşerî, Keşşâf Tefsiri, III, 414.

123 Zemahşerî, Keşşâf Tefsiri, III, 418.

124 Hûd, 11/47.
} 
gerçekleştirmeme konusunda kararlılı̆̆ını göstermiş, duyduğu pişmanlığı dile getirerek tövbesindeki samimiyetini ortaya koymuştur. ${ }^{125}$

\section{Musa Peygamberin Pişmanlığı ve Tövbesi}

Kur'an'da en çok ismi geçen peygamber Musa Peygamberdir ve hayatı büyük mücadelelerle geçmiştir. Allah müminlerden onun hayatını okumalarını ve üzerinde düşünmelerini istemektedir. Hayatının her döneminde tevhit inancını tebliğ etmeye çalışmış, kimi zaman siyasi otoriteye, kimi zaman köle ruhlu toplumuna karşı sabırla mücadele etmiştir. Aynı zamanda iç dünyasında bir iç muhasebesi ve mücadelesi de yaşamıştır. Her insanın bilinçaltında merak ettiği "Acaba Allah'ı görebilir miyim?" sorusunu kolektif bilinçten dişarıya taşımıştır. Sorduğu sorunun haddini aştığını görünce hemen pişmanlığını Allah'ı tenzih ederek dile getirmiştir. ${ }^{126}$ Allah'ın, gözlerin görmesinden, duyuların idrakinden üstün olduğunu, bu husustaki talebiyle ölçüyü aştığını belirtmiş, ne olursa olsun her durumda iman edenlerin ilki olarak, imanını tazeleyerek yoluna devam edeceğini belirtmiştir. ${ }^{127}$ Musa Peygamber'e ikinci kez pişmanlık yaşatan olay; kendi

440 kavminden olan birini haklı görmesi sebebiyle meydana gelmiştir. İstemeden de olsa iman etmeyen bir kişinin ölümüne neden olmakla büyük bir imtihan yaşamıştır. Gerçekleştirdiği eylem nedeniyle pişman olmuş ve tövbe etmiştir. ${ }^{128}$ Netice itibariyle Kur'an Musa Peygamber örneği üzerinden büyük hatalar yapıldığında bile pişmanlık duygusunun nasıl aktif hale getirileceğini göstermektedir.

\section{Davud Peygamberin Pişmanlığı ve Tövbesi}

Yaşadığı bir olaydan nedamet duyan ve kendine has tövbesiyle özel bir duruş sergileyen Davud peygamberin anlatıldığı ayetler insana farklı bir perspektif kazandırmaktadır. Ayetlerde Davud Peygamberin vermiş olduğu bir hüküm anlatılmaktadır. ${ }^{229} \mathrm{Bu}$ konuda farklı görüşler olsa da tercih edilen bir görüsse göre, Davud Peygamber yanına girenlerin normal kapıdan girmeyerek anormal bir yolu tercih etmeleri ve kendisine zarar vereceklerini düşündüğü için hüküm verme konusunda aceleci davranmıştır. Davud Peygamber'in hüküm vermede acele etmesinin pişman olmasına neden

\footnotetext{
125 Razi, Tefsirü'l-Kebir, XIII, 40.

126 el-A'râf, 21/143.

127 Seyyid Kutup. Fî Zilâli'l-Kur ân , VI, 254; Mâtürîdî, Te'vilatül Kur'an Tercümesi, VI, 67.

128 Mukâtil b. Süleymân, Tefsir-i Kebir, III, 269; Seyyid Kutup. Fî Zılâli'l-Kur'ân , XI, 233-234.

129 Sâd, 38/21-24.
} 
olduğu düşünülmektedir. ${ }^{130} \mathrm{Bu}$ kıssa temsili bir anlatım da olsa iman etmeyenlerin ya da ekonomik gücü olmayanların ortaklıkta haksızlık yapacağının düşünülmesinin hatalı değerlendirmelere neden olacağını göstermektedir. Yaşanan bu olayda Davud Peygamber davalı olanların melek olduğunu ve imtihandan geçtiğini anlayınca Rabbinden af dilediği bildirilmektedir. ${ }^{131}$ Kur'an'da Davud Peygamberin hatasını fark ettiği gibi tövbesini kelimelerle ve beden dilinin bir tezahürü olan secdeyle yaptığ1 anlatılmaktadır. Dolayısıyla Davud Peygamberin secde eylemi kulluğun en zirve boyutunu gösteren secde ameliyle tövbe edileceğini göstermektedir. ${ }^{132}$

\section{Yunus Peygamberin Pişmanlığı ve Tövbesi}

İnsanın en zorlu mücadelesi kendi benliğiyle yaşadı̆̆ı mücadeledir. Fitratta olan acelecilik çoğu zaman sabır mekanizmasını yavaşlatmaktadır. Sabretmek pasif bir direniş olarak düşünüldüğü zaman acelecilik aktif bir hâl almaktadır. Sabır aslında pasif bir eylem değildir, insanın melekelerini güçlendiren ve özdenetimi arttıran aktif bir eylemdir. Yunus Peygamber'in hayat serüveninde sabır konusundaki imtihanı önemli bir örneklik teşkil etmektedir. ${ }^{133}$ Yunus Peygamber'e kalabalık bir topluma hakikati anlatma görevi verilmiştir. ${ }^{134} \mathrm{O}$ tevhit inancını tebliğ etmeye çalışırken toplumundan olumsuz tepkiler görmüştür. $\mathrm{Bu}$ olumsuz tepkiler karşısında sabırsız davranmış, halkının doğru yola geleceğinden ümidini kestiği için ya da kavminin başına bir bela gelmesinden korktuğu için Allah'ın izni olmadan ülkesini bir köle gibi kaçarak terk ettiği bildirilmektedir. ${ }^{135}$ Kur'an'da Yunus Peygamber'in sabırsız davrandığı için kınanacak bir iş yaptığı ifade edilmektedir. ${ }^{136}$ Sabırsız davrandığ 1 için bir balık tarafından yutulmuş, karanlıklar içinde kalmıştır. İçine düştüğü bu durum hatasını anlamasını sağlamıştır. ${ }^{137}$ Yaşadığı pişmanlığını Allah'ı tesbih ederek ve yaptığı hatayla kendisine zulmettiğini itiraf ederek pişmanlığını dile getirip tövbe etmiştir. ${ }^{138}$ Netice olarak insanlar gibi peygamberler de pişmanlık duygusunu yaşatan olaylarla karşılaşmışlardır. Kur'an peygamber

\footnotetext{
130 Maşallah Turan, “Davut Peygamber Kıssasında Geçen “Na'ce Koyun Bahsi” Üzerine Değerlendirmeler", Social Mentality and Researcher Thinkers, 6/33 (Mayıs 2020): 1268.

131 Mâtürîdî, Te'vilatül Kur'an Tercümesi, XII, 256; Seyyid Kutup. Fî Zilâli'l-Kur'ân , XII, 383-384.

132 Mâtürîdî, Te'vilatül Kur'an Tercümesi, XII, 237-238.

133 el-Enbiyâ, 21/87.

134 es-Sâffât, $37 / 147$.

135 Mâtürîdî, Te'vilatül Kur'an Tercümesi, XII, 209-210; Zemahşerî, Keşşâf Tefsiri, V, 760.

136 es-Sâffât/142.

137 es-Sâffât, 37/142-143.

138 el-Enbiyâ, 21/87.
} 
prototipleri üzerinden pişmanlığa götüren yanlış tasavvur, bilgisizlik, haddi aşan merak, öfke ve sabırsızlık konularındaki nedameti ve pişmanlığın tövbeyle nasıl aktif bir hale getirileceğini anlatmaktadır.

Peygamberlerin küçük gibi görünen olaylardan pişmanlık duymaları ve hemen tövbe etmeleri önemli bir mesaj vermektedir. Yapılan küçük bir yanlış pişmanlık duygusu vermez ve tövbesi olmazsa o yanlışlar büyüyerek insanın hayatının tamaminı kaplayabilmektedir. Peygamberlerin bu farkındalık içeren yaklaşımları insanları hatalar konusunda dikkatli olmaya çağırmaktadır. Tövbe günahı terk etmek, yanlıştan dönmek, vazgeçmek anlamlarına gelmekte, yapılan yanlış eylemden dönmeyi gerektirmektedir. 139 Tövbe, kulun yaptı̆̆1 hatadan pişman olması, hatasından dolayı Allah'tan af dilemesi ve bir daha yapmama iradesinde bulunması aynı zamanda kötülük yapmaktaki ısrarından vazgeçerek iyilik yapmaya yönelmesi ve Rabbine yakınlaşmasıdır. Bir başka ifadeyle kulun fıtrat çizgisine dönmesidir. ${ }^{140}$ Tövbe eylemi, yanlış davranışların psikolojik ağırlı̆̆ından kurtularak hatayı telafi imkânıdır. ${ }^{141} \mathrm{Bu}$ eylem insan psikolojisinde kalıcı suçluluk hissinin neden olduğu ruhsal rahatsızlıkları gideren bilişsel bir eylemdir. ${ }^{142}$ Doğruya yönelişi, inâbeyi ifade eden tövbe, inançsızlıktan imana, günah eylemlerinden sevap eylemlerine yönelimdir. Bu yönelim kişinin ruh dünyasında mutluluk, huzur, denge gibi pek çok güzellikler getirmektedir. ${ }^{143}$ Dolayısıyla peygamber modelleri üzerinden anlatılan ve farkındalık eylemi olan tövbeyle aktive edilen pişmanlık dünyada insana verilmiş bir imkânı ifade etmektedir.

\section{Sonuç}

Kâinatın gözbebeği mesabesinde yaratılan ve yaratılış amacına uygun donatılan, ontolojik bir gerçekliğin tezahürü olan insan birçok duyguyu bir arada yaşamaktadır. Kimi zaman tasavvur ya da eyleminden huzur duyarken kimi zaman tasavvur ya da eylemi sebebiyle pişmanlık duygusuyla yüzleşmektedir. Pişmanlık insanın tasavvurundaki, eylemlerindeki hatalarının farkına varması ve hatalarından dolayı nadim olmasına yönelik bir çabayı ifade etmektedir. İnsanlık kadar kadim bir tarihi

\footnotetext{
39 el-İsfahanî. Müfredat, 169.

140 Ahmet Akbaş, Kur'an'da İnsanın Mutluluğu, (İstanbul: Rağbet Yayınları, 2015), 296.

141 Asım Yapıcı, İslam'da Tövbe Ve Dini Yaşayıştaki Rolü, (İstanbul: Beyan Yayınları, 1997), 295.

142 M. Osman Necati, Kuran Ve Psikoloji, (Ankara: Fecr Yayınları,1998), 264-265.

143 Abdurrahman Kasapoğlu, "Kur'an'da İnâbe Kavramı: Dini Tecrübe Açısından Bir Yaklaşım”, Tasavvuf, 9/22 (2007):145.
} 
olan pişmanlık, kişinin zihnini ve gönlünü kaplayan, derin bir iç acısıdır. Pişmanlıkla ilgili çalışmamızın sonucunda pişmanlık duygusunun yaşanmasına neden olan tasavvur, inanç ve eylem olmak üzere üç önemli faktörün bulunduğu anlaşılmaktadır. Vahyin ve psikolojik yaklaşımların verdiği bilgiler 1şığında dünyada yaşanan pişmanlığı olumsuz, insanın hayatını tüketen bir duygu olmadığını, bu tecrübeyi yönetebilen kişiler için köklü değişimler meydana getirebilecek bir tecrübe olabileceği, bireyin dünyada bunalımlar yaşamasına, ahirette azapla karşılaşmasına engel olacağ1 anlaşılmaktadır. Pişmanlığı yönetmek için yapılacaklar şöyle sıralanabilir: Yapılan yanlış eylemden nadim olup tövbe etmek, yanlış eyleme sebep olan düşünceyi bulup, değerlendirmek, köklü değişim için ümitli olmak, yanlış olan eylemi bir daha yapmama kararı almak, pişmanlık yaşayan peygamberlerin hayatlarından ve tövbelerinden dersler çıkarmak, yaşanılan bu durumdan Allah'a sığınmak, tövbe edilen yanlış eyleme dönmemek için o eylemi oluşturacak ortamlardan uzak durmak ve alınan kararlarda kararlılık göstermek için Allah'a dua etmek.

Pişmanlık duygusu insanlık tarihinin başladığı yerde Hz. Adem ve eşiyle yeryüzünde ilk görüntüsünü vermiş, kadim bir tecrübedir. Bu tecrübe insana acizliğini, zayıf yönlerini gösterirken aynı zamanda potansiyelini kullanıp bu durumla baş edebilme becerisini geliştirmesine olanak tanımaktadır. Bu tecrübe kişinin iradesini kullanabilme yeteneğini açı̆̆a çıkarmaktadır. Pişmanlık tecrübesini doğru yönetebilen kişi, kozasından çıkan kelebek gibi kendisini esir alan yanlış düşünce ve eylemlerden özgür olma noktasına gelmektedir. Kur'an'da pişmanlık tecrübesinin değişim ve dönüşüme sebep olan tövbeyle aktive edildiğinde insanı dünyevi ve uhrevi mutluluğa taşıyacağı müjdelenmektedir. Dünyada yaşanan pişmanlıkları tövbeyle aktive edip imkân haline getirebilme gücü Allah'ın insana verdiği bir imkandır. Pasifize edilmiş, tövbesi olmayan pişmanlıklar ise insanın kendisini yanlışlar içine mahkûm edip, iradesini yok etmesidir.

\section{Kaynakça}

Akalın, Şükrü Haluk vd. Türkçe Sözlük. 11. Baskı. Ankara: Türk Dil Kurumu, 2011.

Akbaş, Ahmet. Kur'an'da İnsanın Mutluluğu. İstanbul: Rağbet Yayınları, 2015.

Akdemir, Fuat. "Kur'an'da İtaat Kavramı ve Peygambere İtaatin Mahiyeti". KADER Kelam Araştırmaları Dergisi 11 / 1 (Ocak 2013): 426-428. 
Altuntaş, Abdurrahman. "Kur'an'da İnsanın Salih Olma Süreci”. Gümüşhane Üniversitesi İlahiyat Fakültesi Dergisi 7/13 (2018): 81-113.

Atay, Hüseyin. “Kur'an'a Göre Tövbe ya da Bilinci Yenilemenin İmkânı”. İslamiyat Dergisi 1/.3 (1998).

Bayraklı, Bayraktar. İnsanlığın Vebası Şirk. İstanbul: Düşün Yayıncılık, 2015.

Bayraklı, Bayraktar. Yeni Bir Anlayışın Işığında Kur'an Tefsiri. İstanbul: Bayraklı Yayınları, 2003.

Dai, Muhammed Ali. İslam, Ferheng-i Nizam: Farisi Ba Farisi. Tahran: Şirket-i Daniş, 1362.

Devellioğlu, Ferit. Osmanlıca-Türkçe Ansiklopedik Lügat. Ankara: Kurtuluş Ofset Basımevi, 1984.

Doğan, D. Mehmet. Büyük Türkçe Sözlük. Ankara: Vadi Yayınları, 2003.

Ebu Mansur el- Mâtürîdî. Te'vilatül Kur'an Tercümesi, çev. Kemal Sandıkçı. İstanbul: Ensar Neşriyat, 2017.

Ebu'l-Kasım Cârullah Mahmud b. Ömer Zemahşeri. Keşşaf Tefsiri. çev. Abdülaziz Hatip. İstanbul: Türkiye Yazma, Eserler Kurumu Başkanlığı, 2017.

Epiktetos. Düşünceler ve Sohbetler. çev. Cemal Sürer. İstanbul: Kaknüs Yayınları, İstanbul. 1999.

Fahrettin Razî. Mealimu Usul'id Din (İslam İnancının Ana Konuları). çev. Nadim Macit. Erzurum: İhtar Yayıncilık, 1996.

Fahrettin Razî. Tefsîr-i Kebir (Mefatihu'l-Gayb). çev. Sadık Kılıç v.dğr. İstanbul: Huzur Yayınevi, 2002.

Gazalî, Ebu Hamid Muhammed. İhya-u Ulumi'd-Din. çev. Ahmed Serdaroğlu. İstanbul: Bedir Yayınevi, t.y.

Gilbert, Daniel T. V- Morewedge, Carey K.-Risen, Jane L.-Risen, Wilson, Timothy D.. "Looking Forward to Looking Backward The Misprediction of Regret, Pyschological Sience". Research Report 15/5 (May 2004): 346-350.

İbn Hanbel, Ebû Abdullah Ahmed b. Muhammed eş-Şeybânî. Müsned. 1 Cilt. Beyrut: Mektebetü'1-İslamî, 1405/1985.

İbn Manzur, Ebu'l-Fadl Cemalüddin Muhammed b.Mükerrem. Lisanu'1-Arabi'1Muhit, 3.Baskı. Beyrut: Dâru'l-Fikr, 1994.

Kadı Abdülcebbar. Şerhu'l-Usuli'l-Hamse. çev. İlyas Çelebi. İstanbul: Türkiye Yazma Eserler Kurulu Başkanlığı, 2013.

Kara, Necati. Kur'an'da Beden Dili. İstanbul: Bilge Yayınları, 2004.

Mukâtil b. Süleymân. Tefsir-i Kebir. çev. M. Beşir Eryarsoy. 2. Baskı. İstanbul: İşaret Yayınları, 2017. 
Mustafa Çağrıcı, "Cimrilik". Türkiye Diyanet Vakfı İslâm Ansiklopedisi, Ankara: TDV Yayınları, 1993. VII, 4.

Mustafa Çağrıc1, "İnat". Türkiye Diyanet Vakfi İslâm Ansiklopedisi, Ankara: TDV Yayınları, 1993, XXII, 264- 265.

Ömer Mahir Alper, "İtaat”. Türkiye Diyanet Vakfi İslâm Ansiklopedisi, 23:444. Ankara: TDV Yayınları, 2001.

Râğıp el-İsfahanî. Müfredatu Elfazi'l-Kur'an, thk: Safvab Adnan Davudi. Dımaşk: Darü'l-Kalem, Beyrut: Darü'ş-Şamiyye, 2002.

Reber, Arthur S. The Pengiun Dictionary of Psychology. London: Pengiun Books, 1985.

Rycroft, Charles. Psikanaliz Sözlüğü. çev. M. Sağman Karatekin. İstanbul: Ara yayınları, 1989.

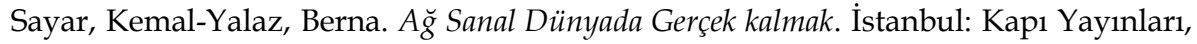
2019.

Schopenhauer, Arthur. Yaşam Bilgeliği Üzerine Aforizmalar. İstanbul: Türkiye İş Bankası Kültür Yayınları, 2011.

Seyyar, Ali. Ahlak terimleri (ansiklopedik sözlük): Ingilizce-Almanca karşıllklı Türkçe açıklamalı. İstanbul : Beta Basım Yayım , 2003.

Saygın, Oğuz - Layiç, Şafak. Resimli Beden Dili. İstanbul: 4x4 Yayıncılık, 2006.

Seyyid Kutup. Fî Zılâli'l-Ḳur'ân, çev. Bekir Karlığa v. dğr. İstanbul: Hikmet Yayınevi, 1970.

Taşçı, Özcan, "Nedâmet". Türkiye Diyanet Vakfi İslâm Ansiklopedisi, Ankara: TDV Yayınlar1, 2006, XXXII, 509.

Turan, Maşallah. “Davut Peygamber Kissasında Geçen “Na'ce Koyun Bahsi” Üzerine Değerlendirmeler", Social Mentality and Researcher Thinkers, 6/33 (Mayıs 2020): 1257-1275. DOI: http:/ / dx.doi.org/10.31576/smryj.573

Ünal, Ali. Kur'an'da Temel Kavramlar. İstanbul: Beyan Yayınları, 1990.

Yariz, Enes. “Kur'an'a Göre Hidâyete Ermede İnsanın Rolü”, İ.Ü. İlahiyat Fakültesi Dergisi, İnönü Üniversitesi İlahiyat Fakültesi Dergisi 8 / 2 (Aralık 2017): 358-84.

Yazır, Elmalılı Muhammed Hamdi. Hak Dini Kur'an Dili. İstanbul: Matbaai Ebuzziya, 1935.

Zeelenberg, Marcel-Breugelmans, Seger M.,."The Role of Interpersonal Harm in Distinguishing Regret From Guilt". Emotion 8/5 (2008): 589-96.

Zeelenberg, Marcel. "The Use of Crying Over Spilled milk: A Note On The Rationality and Functionality Of Regret". Philosophical Psychology 12/3 (1999): 325-40. 
Doi: 10.34247/artukluakademi.807254 | Araştırma Makalesi

Handan Yalvaç Arıcı

\section{Regret from the Perspective of the Qur'an}

Citation/৫: Yalvaç Arıcı, Handan, Regret from the Perspective of the Qur'an, Artuklu Akademi, 2020/7 (2), 417-448.

\section{Extended Abstract}

Regret is a cognitively based emotional act that creates awareness starting with human history. For every person, there are frames of the experience of regret in his life journey. Everyone, big or small, more or less, each person has an experience to do with this feeling. There are many expressions of this cognitivebased emotion reflected in the word. There are many expressions of this cognitive-based emotion reflected in theutterance. "I wish I had acted differently", "I wish I hadn't done it in this way", "I wish I had tried a little more", "I wish it wasn't like this.", "Why did it happen like this?" Such statements are the verbal reflections of the feeling of regret. The verbal, physical and emotional expressions of this emotion occur in proportion to the effect of the negative event or situation on emotions of the person. Regret is usually an emotional state that occurs in case of being responsible for the occurence of a negative case orfeeling in charge of the relevant case. This emotion has characteristic behavioral consequences. There is an effort to make up for the subject event that causes that feeling in the experience of regret originated and to take a precaution to prevent encountering this feeling again in the future. This feeling is a functional emotion that supports one's learning from his mistakes. When a person regrets, it is a functional introvertmovement that motivates him to evaluate his imagination and actions and turn to the right. This inner experience plays a functional role in the person to compensate for the event. The feeling of regret usually consists of a combination of two elements. First of all, the wrong decision made or the wrong behavior in a matter, and the adverseresult that comes afterwards are the two basic elements of this feeling. The person lives this experience both because of the wrong decision and the result of the decision. The person who experiences this feeling feels responsible for making the wrong decision and often develops solutions that can compensate for this situation.

The experience of regret is the realization of the wrongness in the discourse or action of the person, and giving up that action and the rhetoric and directing to the right thought and action. In order for a person to regret, he must have knowledge and equipment to realize his mistake. Günümüz insanı modern itiraflar adı altında pişmanlık duymama ve yaptığı yanlış söylem ve eylemlerinden üzüntü hissetmeme tasavvuruyla inşa edilmektedir. Today's people are shapedfor the sake of modern confessions, with the discernmentof not feeling regret and not feeling sorry for their wrong statements and actions. 
However, the experience of regret is an internal experience of self-evaluation, sometimes as a result of conscious and sometimes unconscious actions. Regret becomes active when the person who experiences this experience focuses on the action, not on himself; realizes the wrongdoing of the action and decides to take the right action. Even though the wrong discourse and actions are realized, persistently insisting on the wrong can lead to an experience of irreversible regret. In order not to experience an irreversible regret, it is necessary to organize the imagination by analyzing the origin of the actions in the mind. Otherwise, millimetric faultsand deficiencies in the concept cover large areas of action. If regret does not lead the individual to the right behavior, the behaviors performed become habits. If regret is experienced actively, creates awareness and directs the individual to repent, then it becomes an opportunity that matures the individual and makes him use his will to return from his wrongdoing. A person who insists on his faultand does not retreatfrom that mistake turns his / her mistake into a habit and tends to act with automatic behavioral patterns without evaluating the accuracyor inappropriate inclusion of his behavior. As a result, irreversible regrets are experienced. The Quran explains the penitence that will cause regret in the world and the hereafter, and constructs a vision of repentance by telling the repentance phenomenon and repentance of the prophets. It provides information so that the addressee can manage regret.

As a result of the study, it is seen that every person, regardless of their social environment, position, age, and gender, experiences a feeling of regret for their imagination and actions in some frames of the life scene. When the regret is evaluated from the perspective of the Quran, it is understood that there are many premisesthat cause the experience of regret. Especially, thoughts such as the feeling of laziness, haste, indecision, selfishness, insulting mistakes, attributing mistakes to others, attributing eternity to blessings, making plans independent of God, cause the feeling of regret. Beliefs that cause regret are shirk, denying Allah's verses, being heedless of Allah, being stubborn in denial of the belief, not obeying Allah and His Prophet, not believing in the hereafter and not taking advice from the Quran. The actions that cause the feeling of regret are generally listed as acting in accordance with the vain fancies and aspirations, being stingy or wasting, making wrong friends and friends, not committing righteous deeds, being subjected to wrong leaders, being cruel and trying to turn from the way of Allah. Actions to be taken in order not to feel regret in the world and in the hereafter according to the Quran are as floowsTo construct imagination by revelation, to place Allah in the intention of actions, to make a sincere effort not to make mistakes, to engage in intellectual reading activities with continuity on understanding the Quran, the universe and the hadith, not to act with the psychology of postponement in doing righteous deeds, vainwords and not to waste time with idle deeds, to show determination to leave even if the mistakes are minor, to prefer to be with groups that do righteous deeds, to make friends and allieswho will warn when a wrong action is taken, and to act without waiting for doomsday and torment to come. 
In this study, the concept of regret is explained, active and passive types of regret are evaluated, regret with repentance and leading to change in behavior is called active; regret with continuity in wrong actions without repentance is called passive regret. The aim of the study is to reveal the actions leading to regret and regret from the perspective of the Quran. Content analysis method, one of the qualitative research methods, is used in the study, the subject of regret is divided into categories and subcategories, the limits of regret are drawn in line with the opinions of experts, and the problems related to the experience of regret and regret are evaluated in detail. As a result of the research, the regrets in the Quran are classified, the way how the prophets compensated their regrets is presented and an active repentance perspective is put forward. 